\title{
Chapter 11 \\ Tax-Benefit Reforms and Structural Models for Labour Supply
}

\author{
Henk-Wim de Boer, Egbert Jongen, and Mauro Mastrogiacomo
}

\subsection{Introduction}

Faced with tight budget constraints, policymakers are reconsidering their taxbenefit policies and the trade-off between equity and efficiency (Mirrlees, 1971). Redistribution from rich to poor households, or from singles to couples, distorts the labour supply decision or effort more generally, and subgroups may respond differently to this redistribution. Understanding the heterogeneity in labour market responses of different groups, traditionally measured by the wage elasticity of labour supply, ${ }^{1}$ is thus essential for an efficient design of tax incentives.

\footnotetext{
${ }^{1}$ A related literature studies the elasticity of taxable income to measure the distortions of taxation (Saez et al., 2012a). However, there is an active debate on whether the elasticity of taxable income is a sufficient statistics to measure the distortions from taxation (Chetty, 2009).

The views expressed in this chapter do not necessarily reflect the position of CPB Netherlands Bureau for Economic Policy Analysis, Leiden University, DNB, the Eurosystem, VU University Amsterdam or Netspar. This chapter draws on Jongen et al. (2014), CPB (2015), Mastrogiacomo et al. (2017) and De Boer and Jongen (2017).

H.-W. de Boer $(\square)$

CPB Netherlands Bureau for Policy Analysis, The Hague, Netherlands

e-mail: H.W.de.Boer@cpb.nl

E. Jongen

CPB Netherlands Bureau for Policy Analysis, The Hague, Netherlands

Leiden University, Leiden, Netherlands

M. Mastrogiacomo

Economic Policy Department, De Nederlandsche Bank, Amsterdam, Netherlands

VU University of Amsterdam, Amsterdam, Netherlands

(C) Springer International Publishing AG, part of Springer Nature 2018

J. de Haan, J. Parlevliet (eds.), Structural Reforms,

https://doi.org/10.1007/978-3-319-74400-1_11
} 
In this chapter, we exploit a very large administrative dataset on Dutch households, the Arbeidsmarktpanel (Labour Market Panel) of Statistics Netherlands (2012), to estimate the behavioural responses to changes in financial incentives. Specifically, the size of the dataset allows us to estimate the preferences and corresponding labour supply elasticities for a large number of subgroups on the Dutch labour market. In the estimations we use a discrete choice model for labour supply (Aaberge et al., 1995; Van Soest, 1995; Keane and Moffitt, 1998; Aaberge et al., 1999; Brewer et al., 2006; Bargain et al., 2014). ${ }^{2}$ We subsequently use the estimated preferences in a behavioural microsimulation model, and simulate the labour supply effects of a large number of potential reforms that feature prominently in the policy debate. We also simulate the effects of the reform package of the Tax Plan 2016, which was discussed extensively in Dutch parliament.

To preview our results, we uncover large heterogeneity in the labour supply elasticities of different demographic groups and decision margins. We find that childless singles and men in couples hardly respond to changes in financial incentives, whereas single parents and women in couples with young children are quite responsive. We further find that most of the response is in the number of persons employed, not in the response in hours worked per week per employed, and that cross-elasticities for women in couples are non-negligible. These findings have the following implications for tax-benefit reforms. Reductions in the marginal tax rate, via e.g. a decrease in the tax bracket rates, hardly affect labour supply. Reductions in income support for low-income households are relatively effective in stimulating labour supply, but increase income inequality. However, higher in-work benefits for low-income workers are also relatively effective, and do not increase income inequality. Furthermore, the most effective instruments are tax credits and (child care) subsidies for single parents and secondary earners with young children. These groups are the most responsive to changes in financial incentives. The Tax Plan 2016 stimulates labour supply in persons and in hours. Indeed, the Tax Plan 2016 contains a number of policy changes that are relatively effective in stimulating labour supply, like the increase in the in-work tax credit for low-income workers, the in-work tax credit for single parents and secondary earners with a young child and an increase in child care subsidies.

The outline of the chapter is as follows. Section 11.2 gives some context on the Dutch labour market and gives a brief description of the Dutch tax-benefit system in 2015, which will serve as the baseline for our policy simulations. Section 11.3 describes the structural discrete-choice model and the empirical methodology. Section 11.4 discusses the data used in the empirical analysis, and Sect.11.5

\footnotetext{
${ }^{2}$ Discrete choice models have become popular in labour supply analysis because they greatly simplify the analysis of (joint) labour supply decisions when there are kinks and non-convexities in the budget set (due to e.g. the tax-benefit system).
} 
presents the empirical results in terms of labour supply elasticities. Section 11.6 presents simulations results for a large number of tax-benefit reforms, including the reform package of the Tax Plan 2016. Section 11.7 discusses our findings and concludes.

\subsection{The Dutch Labour Market and Tax-Benefit System}

Over the past decades, the Netherlands has witnessed a number of relevant demographic changes. ${ }^{3}$ The share of couples with children has declined and the share of couples without children has increased. Furthermore, the overall share of couples has been declining, while the share of singles and single parents is now much higher than a few decades ago. Hence, studying the behavioural responses by singles and single parents has become more important over time. The participation rate of women has increased spectacularly. In the mid 1970s, the participation rate of Dutch women was one of the lowest in Europe, whereas by now it is one of the highest. The participation rate of men was and remains high by international standards. This has important implications for labour supply elasticities, as cross-country studies (Bargain et al., 2014) and studies that look at labour supply elasticities over time (Blau and Kahn, 2007) suggest that labour supply elasticities are much lower when the participation rate is higher. ${ }^{4}$ In terms of hours worked per week, however, Dutch women still work much less than their European counterparts (about $10 \mathrm{~h}$ per week less on average), and so do Dutch men (about $5 \mathrm{~h}$ per week on average). So there appears to be still a lot of potential on the intensive margin of labour supply. Below, we consider whether this is the case.

Turning to the tax-benefit system, like most OECD countries, the Netherlands has a progressive income tax system. ${ }^{5}$ Labour income is taxed individually and marginal income tax rates increase with income. Table 11.1 gives an overview of the most relevant elements of the Dutch income tax system in 2015 for the current study. The lowest marginal rate in 2015 is $36.5 \%$ payable over a taxable income of up to 19,822 euro. For incomes ranging from 19,822 to 57,585 euro, a marginal tax rate of $42 \%$ applies. The highest marginal tax rate is $52 \%$.

The tax system contains many tax credits, tax deductions and means-tested benefits, that make it rather complex. ${ }^{6}$ Tax credits reduce the total amount of income tax people need to pay. Over the past decade, all instruments described in Table 11.1

\footnotetext{
${ }^{3}$ De Boer and Jongen (2017) give an overview of changes in the shares of the different household types, and the changes in the participation rates and hours worked per week by household type.

${ }^{4}$ Indeed, as younger women more often participate in the labour market, their behaviour becomes more similar to that of men within the same cohort. Our recent data show indeed much lower labour supply elasticities for women, relative to those estimated in studies based on older data.

${ }^{5}$ For the overview of the tax-benefit system we draw on CPB (2015).

${ }^{6}$ We exclude tax deductions from the analysis, since these could not be observed in our dataset.
} 
Table 11.1 The Dutch income tax system 2015

\begin{tabular}{|c|c|c|c|}
\hline & Income range & Tax rate & Maximum amount in euro \\
\hline \multirow[t]{4}{*}{ Income taxes } & $0-19,822$ & $36.5 \%$ & 7235 \\
\hline & $19,822-33,589$ & $42.0 \%$ & 13,017 \\
\hline & $33,589-57,585$ & $42.0 \%$ & 23,095 \\
\hline & $>57,585$ & $52.0 \%$ & \\
\hline \multirow[t]{3}{*}{ General tax credit } & $0-19,822$ & & 2203 \\
\hline & $19,822-56,935$ & & $\begin{array}{l}2203-2.32 \% \times(\text { taxable } \\
\text { income }-19,822)\end{array}$ \\
\hline & $>56,935$ & & 1342 \\
\hline \multirow[t]{5}{*}{ EITC all workers } & $0-9010$ & & $1.8 \% \times$ labour income \\
\hline & $9010-19,463$ & & $\begin{array}{l}163+19.7 \% \times(\text { labour } \\
\text { income }-9010)\end{array}$ \\
\hline & $19,463-49,770$ & & 2220 \\
\hline & $49,770-100,670$ & & $\begin{array}{l}2220-4.0 \% \times(\text { labour } \\
\text { income }-49,770)\end{array}$ \\
\hline & $>100,670$ & & 184 \\
\hline \multirow{3}{*}{$\begin{array}{l}\text { EITC working } \\
\text { parents }\end{array}$} & $0-4857$ & & 0 \\
\hline & $4857-32,832$ & & $\begin{array}{l}1033+4.0 \% \times(\text { labour } \\
\text { income }-4857)\end{array}$ \\
\hline & $>32,832$ & & 2152 \\
\hline \multirow[t]{2}{*}{ Childcare subsidy } & & & $90.7 \%$ costs first child \\
\hline & & & 93.3\% costs subsequent children \\
\hline \multirow{6}{*}{$\begin{array}{l}\text { Income dependent } \\
\text { child benefit }\end{array}$} & Income $<19,463$ & & 1 child: 1032 \\
\hline & & & 2 children: 1823 \\
\hline & & & 3 children: 2006 \\
\hline & & & Subsequent child(ren): 106 extra \\
\hline & & & Single parents bonus: 3050 \\
\hline & Income $>19,463$ & & $\begin{array}{l}\text { Max. amount }-6.75 \% \times(\text { taxable } \\
\text { income }-19,463)\end{array}$ \\
\hline \multirow[t]{2}{*}{ Rent subsidy } & Income $<21,950$ & & Single-person household : 4079 \\
\hline & Income $<29,800$ & & Multi-person household: 3759 \\
\hline \multirow[t]{2}{*}{ Health care benefit } & $0-19,500$ & & Singles: 936 \\
\hline & $0-19,500$ & & Couples: 1788 \\
\hline \multirow[t]{2}{*}{ Welfare benefits } & & & Singles: 11,530 \\
\hline & & & Couples: 16,471 \\
\hline
\end{tabular}

Source: CPB (2015) 
have been subject to reform. The general tax credit (Algemene Heffingskorting in Dutch) is now income dependent. The maximum amount is 2203 euro in 2015, and is phased out at $2.32 \%$ to a minimum of 1342 euro. All tax-paying individuals in the Netherlands are entitled to the general tax credit. Then there are a number of tax credits for workers. There is an earned income tax credit (EITC) for all workers (Arbeidskorting in Dutch). Over the first 9010 euro, the EITC increases with income, with a phase-in rate of $1.8 \%$. The subsequent phase-in rate is higher: $19.7 \%$ over the income between 9010 and 19,463 euro (which is approximately the full-time minimum wage in 2015). The maximum amount of the EITC for all workers is 2,220 euro. This amount remains constant for incomes between 19,463 and 49,770 euro. The general EITC is phased out for higher incomes, at a rate of $4 \%$, until the minimum amount of 184 euro is reached. For secondary earners and single parents with a youngest child up to 12 years of age there is a specific income-dependent EITC (Inkomensafhankelijke Combinatiekorting in Dutch). Working single parents and secondary earners receive a base amount of 1033 euro if their personal labour income exceeds the minimum income level of 4857 euro. This targeted EITC rises with income, with a phase-in rate of $4 \%$ up to a maximum of 2152 euro.

Next to tax credits, working parents with young children also qualify for childcare subsidies, which are also income-dependent. The subsidy makes a distinction between the first child and any subsequent children. ${ }^{7}$ The maximum subsidy rate in 2015 is $90.7 \%$ for the first child, and the minimum subsidy rate is $18 \%$. The parental contribution rate increases with income. The maximum subsidy rate for a second child is higher, $93.3 \%$, and the phase-out of the subsidy is less steep than for the first child. The minimum subsidy rate for the second child is $58.2 \%$.

The tax-benefit system also contains several income-dependent benefits that provide income support to low-income households bearing certain costs. These benefits depend negatively on the level of taxable household income, increasing effective marginal (and participation) tax rates (CPB, 2015). Parents can apply for income-dependent child benefits (Kindgebonden Budget in Dutch) for the costs related to their children up to 18 years of age. Households receive an annual amount per child. Households with one child receive a maximum amount of 1032 euro, and households with two children receive a maximum amount of 1823 euro. Single parents receive an additional amount of 3050 euro. This benefit is phased out at a rate of $6.75 \%$. Next, the rent subsidy is an income-dependent benefit that compensates low-income households for rent costs. It depends on household income, household composition and the rent level. The maximum amount in 2015 is 4079 euro for single-person households and 3759 for multi-person households. Finally, the health care benefit is an income-dependent benefit for health care costs. In the Netherlands, standard healthcare insurance is compulsory: adults pay an insurance premium, and their children under the age of 18 are included in the insurance policy for free. The benefit level depends on household income but is independent of actual health care

${ }^{7}$ The first child is the child with the highest number of hours formal childcare. 
expenditures. In 2015, the maximum health care benefit is 936 euro for singles and 1788 euro for couples. This benefit is phased out at a rate of $13.4 \%$. Higher income households are not entitled to health care benefits.

Finally, Table 11.1 also gives the level of welfare benefits, distinguishing between singles and couples. Welfare benefits are minimum benefit payments, at the household level, for households without other means of income to guarantee a minimum standard of living. The welfare benefit is higher for couples (16,471 euro) than for singles (11,530 euro).

\subsection{Structural Model}

We use structural models to estimate the labour supply elasticities of different groups on the Dutch labour market. Households are assumed to maximize a unitary utility function subject to a budget constraint and a time constraint. We use a flexible specification for preferences: a translog utility function, also used in e.g. Van Soest (1995). The choice of hours of work is the result of a coordinated decision of the two adult household members $m$ and $f$. Define $y$ as household income and $h_{m}$ and $h_{f}$ as the number of hours worked by the respective partners. We also explicitly model the use of formal childcare for households with young children, where $c$ denotes the number of childcare hours per week. The most elaborate specification is then as follows:

$$
\begin{aligned}
U^{d}(v)=v^{\prime} \mathbf{A} v+\mathbf{b}^{\prime} v+\mathbf{d}^{\prime} \mathbf{1}[\mu>0], \\
v=\left(\log (y), \log \left(1-h_{m} / T\right), \log \left(1-h_{f} / T\right), \log (c)\right), \\
\mu=\left(h_{m}, h_{f}, c\right),
\end{aligned}
$$

where we use the weekly time endowment $T$ to transform the number of working hours into leisure. ${ }^{8}$ The vector $v$ consists of the logarithms of disposable household income $(y)$, leisure of the man $\left(1-h_{m} / T\right)$, leisure of the woman $\left(1-h_{f} / T\right)$ and hours of formal childcare $(c)$. The matrix $\mathbf{A}$ is the symmetric matrix of quadratic coefficients, and the vector $\mathbf{b}$ contains the coefficients corresponding to vector $v$. The vector $\mathbf{d}$ captures fixed costs of work for men and women. These are fixed costs related to working, which are expected to be negative terms for options where the respective person is working. As shown by e.g. Van Soest (1995), fixed costs are necessary to reproduce the low share of individuals that work only few hours per week. Of course, there are sound economic arguments to include them. Fixed costs of work represent disutility from work such as travelling costs, search costs or market frictions. They also play a crucial role in the distinction between the

${ }^{8}$ We use total number of hours per week, e.g. 168, as the weekly time endowment. Different values for $T$ hardly affected the results. 
extensive (participation) and intensive (hours per week) response to changes in financial incentives. We do not include them in income or leisure, but simply include a dummy in utility metric, as in Van Soest (1995). Similarly, we also include fixed costs of using formal childcare.

We allow for preference variation through observed individual and household characteristics $\mathbf{x}_{2}, \mathbf{x}_{3}$ and $\mathbf{x}_{4}$ in parameters $b_{2}, b_{3}$ and $b_{4}$ :

$$
b_{2}=\mathbf{x}_{2}^{\prime} \boldsymbol{\beta}_{2}, \quad b_{3}=\mathbf{x}_{3}^{\prime} \boldsymbol{\beta}_{3}, \quad b_{4}=\mathbf{x}_{4}^{\prime} \boldsymbol{\beta}_{4},
$$

which are the linear utility terms in leisure of the male, leisure of the female, and hours of formal child care, respectively. The same variation is also allowed for the fixed costs parameters $\mathbf{d}$.

Next to the deterministic part of household utility $U^{d}(v)$ defined above, utility also contains an individual and option specific random utility term $\varepsilon_{j}$, necessary to reproduce heterogeneous choices for otherwise similar individuals as observed in the data:

$$
U\left(v_{j}\right)=U^{d}\left(v_{j}\right)+\varepsilon_{j} .
$$

$\varepsilon_{j}$ is assumed to be identically and independently distributed across individuals and options, according to an Extreme Value Type-I distribution: This results in a convenient multinomial logit specification for the probabilities for observing individuals in particular options (McFadden, 1978).

Households choose their preferred combination of hours of work and childcare from a finite set of alternatives $j \in\{1, \ldots, J\}$. We experimented with a number of discretizations, an interval of $8 \mathrm{~h}$ (a normal working day in the Netherlands) running from 0 to $40 \mathrm{~h}$ gave a good fit to the data and worked well in the estimations. For singles without young children, we then have 6 discrete options, and for couples without young children we have $6 \times 6=36$ discrete options. The discrete choice set becomes larger for households who potentially use formal childcare. Specifically, we have $6 \times 4=24$ alternatives for lone parents with young children, and $6 \times 6 \times 4=$ 144 alternatives for couples with a young children.

Disposable income in each discrete option is calculated as:

$$
y=w_{m} h_{m}+w_{f} h_{f}-T\left(w_{m}, h_{m}, w_{f}, h_{f} ; q\right)-T C\left(p_{c}, c ; q\right)+S\left(p_{c}, c, y_{t} ; q\right),
$$

where $w_{m}$ and $w_{f}$ represent the gross hourly wage for the man and the woman. For households with young children, who potentially use childcare, we also take the costs of childcare $T C($.$) and the childcare subsidy S$ into account. Here, the vector $q$ denotes individual and household characteristics, $T C($.$) is the total cost of formal$ childcare, with $p_{c}$ denoting the price per hour of formal childcare, and $S($.$) is the$ childcare subsidy, which depends on the hourly price of formal childcare, hours of formal childcare, taxable income $y_{t}$ and the age distribution of the children.

For all household types we also estimated models where we allow for the possibility that families which are observationally equivalent might have different 
tastes for work and formal childcare, using the so-called latent classes approach (Train, 2008). We assume that there is a finite number $K$ of latent household classes (or types), with households having homogeneous preferences within each class but heterogeneous preferences across classes. In practice, this means that we estimate a finite mixture model with $K$ parametrizations of the utility function, corresponding to $K$ distinct subsets of our data. All the preference parameters therefore become class-specific, which is equivalent to the assumption that they are drawn from a mass-point distribution (Heckman and Singer, 1984). The full set of parameters to be estimated is then:

$$
\theta=\left(\theta_{1}, \ldots, \theta_{K}\right)=\left(\mathbf{A}_{1}, \mathbf{b}_{1}, \mathbf{d}_{1}, \ldots, \mathbf{A}_{K}, \mathbf{b}_{K}, \mathbf{d}_{K}\right)
$$

Since the classes are by definition unobservable, we cannot determine whether a given household belongs to a specific class or not. Instead, we have to construct household-level probabilities of class membership $P_{i}($ class $=k)$, which reflect how likely it is that household $i$ has the preferences corresponding to class $k$, conditional on the household's choices and other observable characteristics. These probabilities are then used as individual weights for a set of class-specific multinomial logit models with separate parameter vectors $\theta_{k}$.

The resulting log-likelihood function of the finite mixture model has the following form:

$$
\mathscr{L}=\sum_{i=1}^{I} \frac{1}{R} \cdot \sum_{r=1}^{R} \log \left(\sum_{k=1}^{K} P_{i}(\text { class }=k) \cdot \sum_{j=1}^{J}\left(\frac{\exp \left(U_{i j}^{s}\left(v_{r}, \theta_{k}\right)\right)}{\sum_{j^{\prime}=1}^{J} \exp \left(U_{i j^{\prime}}^{s}\left(v_{r}, \theta_{k}\right)\right)} \cdot D_{i j}\right)\right) .
$$

For workers we use observed gross wages, while for non-workers we simulate gross wages by using a Heckman selection model. Similarly, we use observed hourly prices for users of formal childcare and we simulate these prices for non-users of childcare. Jongen et al. (2014) provide a detailed description of the empirical specification and the estimation results for the Heckman selection models for gross hourly wages and prices of childcare. We account for wage heterogeneity and price heterogeneity by taking $R$ draws from the estimated wage and price distribution. ${ }^{9}$ Consequently, there is no analytical solution for the likelihood function and we need to integrate over these distributions. The approach we follow is to maximize a simulated likelihood. We draw $R$ wages, compute the likelihood, and average it out over the $R$ draws. $D_{i j}$ is an indicator function which takes the value 1 for the observed choice, and zero otherwise.

For part of the household types the latent classes models work well, in particular for couples with a youngest child 0-3 and 4-11 years of age. However, for some household types the latent classes models produce implausible results, in particular

${ }^{9}$ The number of draws in our specification with latent classes is 10 , and it is kept relatively low to limit the computational complexity of the model. 
for single parents, with a large share having negative marginal utility of income in the observed choices. For the other household types, the labour supply responses using the latent class models are very similar to the 'homogeneous' model (with only 1 class). Based on these results we decided to use the latent classes models for couples with a youngest child which is $0-3$ or 4-11 years of age, and the homogeneous specification for all other groups.

\subsection{Data}

To estimate the preferences of the different household types we use the Labour Market Panel (in Dutch: Arbeidsmarktpanel) of Statistics Netherlands (2012). The backbone of the Labour Market Panel are the annual observations of the Labour Force Survey (in Dutch: Enquete Beroepsbevolking) for the period 19992009, which contains the education level of adult members of the household. Statistics Netherlands supplements this data set with three additional data sources. First, administrative data from municipalities for the period 1999-2009 (in Dutch: Gemeentelijke Basisadministratie) that contains information on individual and household characteristics like age, ethnicity, ages of the children and area of residence. Second, administrative data from the Social Statistical Panel for the period 1999-2009 (in Dutch: Sociaal Statistisch Bestand) on hours worked and gross income. Third, administrative data on formal childcare from the Formal Childcare Database of the Tax Office for the period 2006-2009 (in Dutch: Wet Kinderopvangtoeslag). With respect to formal childcare, a distinction is made between daycare (children 0-3 years of age) and out-of-school care (children 411 years of age).

We estimate a structural model for the simultaneous choice of labour supply and, if applicable, the use of formal childcare. ${ }^{10}$ Because data on childcare in our data set is available from 2006 onwards, we restrict the sample to the period 20062009. Furthermore, formal childcare subsidies are available to parents up to the point where the child goes to secondary school. Therefore, we only allow households with a youngest child of 0-11 years of age to choose formal childcare. Before the age of 4, children can go to daycare, whereas older children can go to out-of-school care. For households without children, or with a youngest child of 12 years of age or older, the childcare terms in the utility function drop out. We exclude households with missing information on individual or household characteristics. Furthermore, to limit the computational burden, we take a $15 \%$ sample of the full data set for couples and for childless singles. For single parents we use the full sample.

\footnotetext{
${ }^{10}$ Unfortunately, informal childcare is not in our administrative dataset. However, De Boer et al. (2015) show that including informal childcare, calculated as the overlap in working hours of parents minus the hours of formal childcare, does not affect the results.
} 
Individuals who adjust their labour supply in our model are employed, on welfare benefits or without any income resources. We do not model and effectively ignore the labour supply of the following types of individuals: students and retired, disabled or self-employed persons. Below we will refer to these individuals as having 'inflexible' labour supply. We do not include these individuals because we do not have reliable information on their hours worked, or because we are unable to determine their budget constraint. We also drop individuals with unemployment benefits, implicitly assuming that they are constrained in their labour supply choice. Furthermore, we also drop same sex households. Finally, we drop individuals under 18 years of age, and individuals over 63 years of age.

For the empirical analysis, we distinguish between '1-flex households' and '2flex households'. Couples are '2-flex households' when both partners are able to adjust their labour supply, and '1-flex households' if only one partner has a flexible labour supply. However, we account for the 'inflexible' partner income when calculating the budget constraint of the 'flexible' partner. In the estimations we distinguish 15 household types: childless singles (1), single parents with a youngest child aged $0-3,4-11,12-17$ or 18 years of age or older (2-5), adult children living with their parent(s) (6), couples without children with both partner flexible (7), couples without children where only the man is able to adjust his labour supply (8), couples without children where only the woman is able to adjust her labour supply (9), couples where both partners are flexible and with a youngest child aged $0-3,4-11,12-17$ or 18 years of age or older (10-13), couples with children where only the man can adjust his labour supply (14), and couples with children where only the woman can adjust her labour supply (15).

We use the tax-benefit model MIMOSI (Koot et al., 2016) to calculate disposable income for each of the alternatives. MIMOSI is an advanced tax-benefit calculator employed by CPB to determine the redistributional and budgetary effects of reform proposals for the tax-benefit system. MIMOSI calculates the budget constraints very accurately, taking into account taxes, premiums and a large number of groupspecific, income-independent and income-dependent subsidies and tax credits. Disposable income is defined as gross income after taxes, employees' premiums, the nominal health care fee, expenditures on formal childcare and inclusive of childcare subsidies. Disposable income in the utility function, in the estimations and simulations, is in 2006 prices.

\subsection{Empirical Results}

In this section we present the labour supply elasticities for all the subgroups. The estimated preferences, fit of the hours distribution and annual gross wage distributions can be found in Jongen et al. (2014). Discrete choice models do not have an analytical solution for the labour supply elasticity. This has to be simulated. We simulate these elasticities by increasing gross hourly wages by $10 \%$. We present the total elasticity (the percentage change in total hours worked over the percentage 
change in the gross wage rate), and the decomposition of this total elasticity into the extensive margin elasticity (the percentage change in the participation rate over the percentage change in the gross wage rate) and the intensive margin (the percentage change in hours worked by the employed over the percentage change in the gross wage rate).

Figure 11.1 gives the simulated labour supply elasticities for couples in which both partners can choose whether or not to work and for how many days per week. We estimate this for several subgroups, where subgroups are defined by the age of the youngest child, including a category for flexible couples without children. We find small, positive labour suppy elasticities for men, see panel (a). The labour supply elasticities are much higher for women, both on the extensive margin and on the intensive margin, see panel (b). Furthermore, the labour supply elasticities for women in couples are particularly high when the youngest child is 0-3 years of age (pre primary school age) or 4-11 years of age (primary school age). Figure 11.2 gives the so-called cross elasticities for these couples, i.e. the percentage change in total hours worked by one partner over the percentage change in the gross wage rate of the other partner. Panel (a) shows that cross elasticities are negative but close to zero for men. For women however, the cross elasticities are non-negligible.
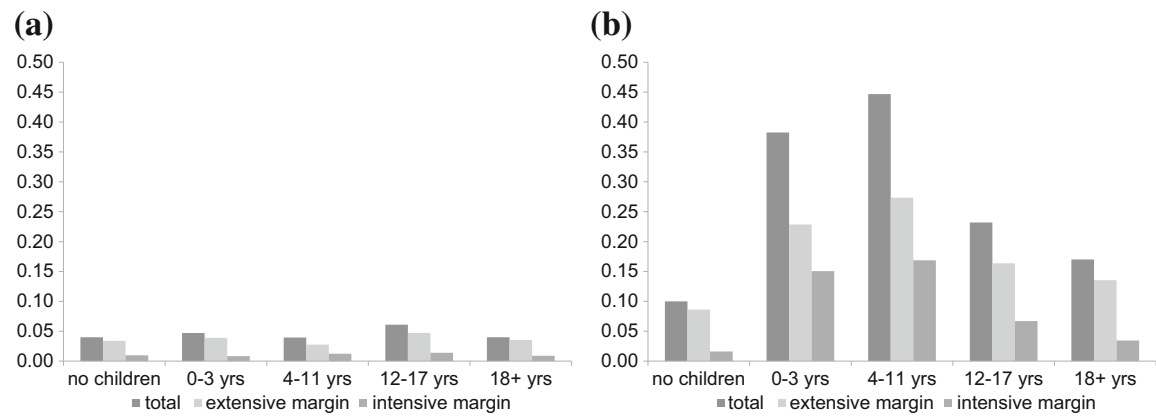

Fig. 11.1 Households with two flexible persons. (a) Men. (b) Women
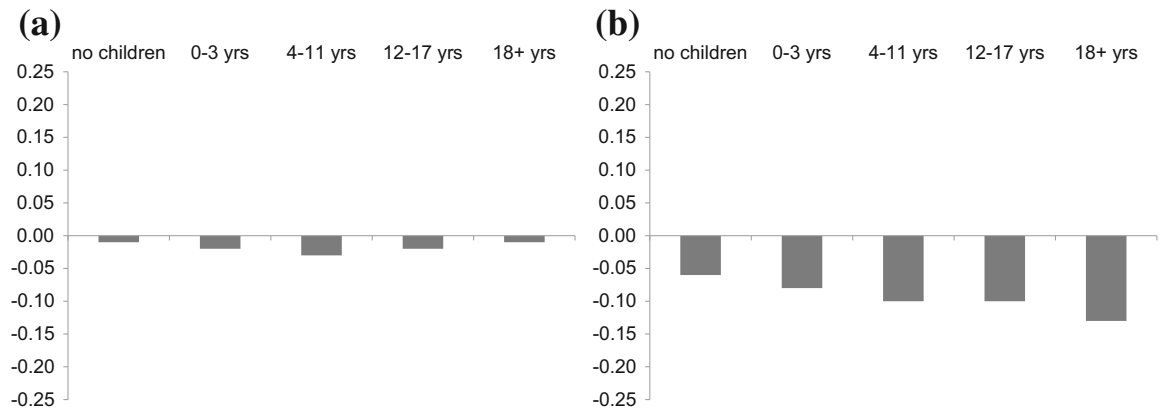

Fig. 11.2 Cross elasticities in households with two flexible persons. (a) Men. (b) Women 

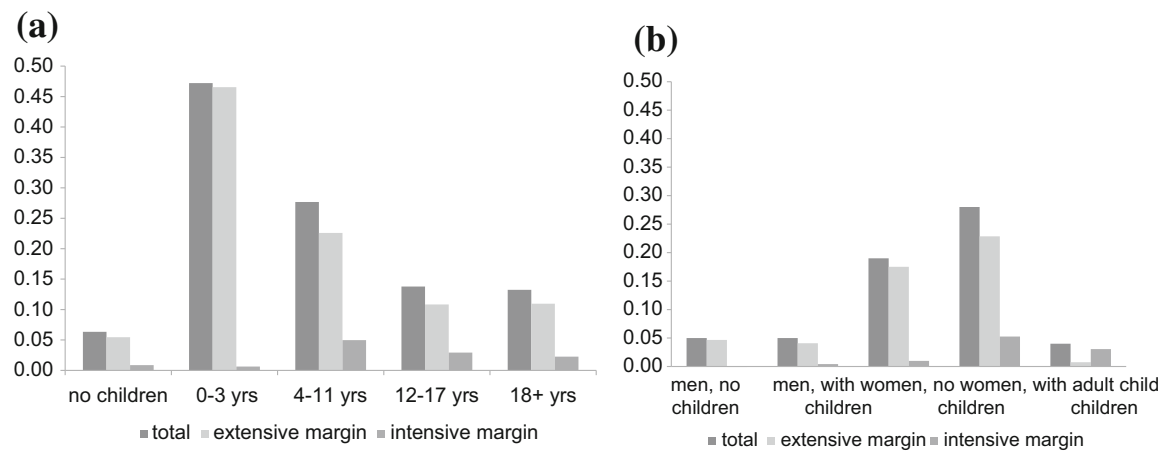

Fig. 11.3 Households with one flexible person, and adult children. (a) Singles and single parents. (b) Individuals with an inflexible partner, and adult children living at home

Figure 11.3 panel (a) shows that the labour supply elasticity is relatively low for singles without children. The labour supply elasticity is much higher for single parents with young children. The labour supply elasticity of single parents whose youngest child is no longer in primary school is much lower, though still higher than for singles without children. Also note that the differences across single parents are primarily driven by differences in the extensive margin elasticity. The intensive margin response for single parents is quite small. ${ }^{11}$

Figure 11.3 panel (b) gives the labour supply elasticities for men and women in couples where one of the partners labour supply is inflexible (because this person is e.g. disabled or retired). For these groups we pool couples with children of all ages. Most men with an inflexible partner work, and typically also fulltime (see Jongen et al., 2014). Hence, there is little upward potential in terms of total hours worked, and they have a relatively low labour supply elasticity. Women have more upward potential in total hours worked, both in terms of the participation rate and in terms of hours worked per employed. Women with an inflexible partner have a higher labour supply elasticity, in particular on the extensive margin. Panel (b) also gives the labour supply elasticity for adult children living at the home of their parents. They have a very high participation rate (when they are not disabled, etc.), resulting in a very low labour supply elasticity.

A more detailed discussion on the empirical results can be found in Jongen et al. (2014). Here, we also present a comparison of predictions by the structural model with the findings from three recent quasi-experimental studies. More specifically, we use the estimated structural model to simulate a number of key reforms implemented in the past and compare the simulated treatment effects with quasi-experimental studies on the same reforms. In particular, we compare the simulated treatment effects of the 2005-2009 reform of childcare subsidies and in-work benefits for

\footnotetext{
${ }^{11}$ Their budget constraint plays an important role here, where working only a few days per week
} often does not generate net income higher than net income out of work. 
households with young children with the estimated treatment effects presented in Bettendorf et al. (2015). Furthermore, we compare the simulated treatment effects of the 2002 reform of the in-work benefit for single parents with the estimated treatment effects presented in Bettendorf et al. (2014). Finally, we compare the simulated intensive margin (hours worked per employed person) elasticities of the structural model with the estimated intensive margin elasticities presented in Bosch and van der Klaauw (2012) and Bosch and Jongen (2013), who use the 2001 tax reform that substantially reduced marginal tax rates. We find that the simulated treatment effects of these past reforms in the structural model are in line with the estimated treatment effects in the quasi-experimental studies.

\subsection{Policy Simulations}

Next, we use the estimated structural models to simulate counterfactual policy reforms, using the 2015 tax-benefit system as the base. We present results for: (1) changes in the tax bracket rates, (2) changes in targeted income support for lowincome households, (3) changes in policies targeted at the extensive margin, (4) changes in policies targeted at working parents with young children and (5) the reform package of the Tax Plan 2016.

\subsubsection{Changes in Tax Bracket Rates}

Table 11.2 gives the simulation results for changes in the tax bracket rates, and the group averages in the base for comparison. ${ }^{12}$ Specifically, we consider the effects of decreasing income tax rate in the first, second, third and fourth (open) income tax bracket so that tax receipts decrease by 1.5 billion euro. ${ }^{13}$ To keep the table to a manageable size, we report aggregate results for the following groups:

- 'Men in couples young. child 0-17' and 'Women in couples young. child 0-17' are respectively men and women in couples with a youngest child $0-17$ years of age, and both partners can choose all hours options.

- 'Men in other couples' and 'Women in other couples' are respectively men and women in couples without children, in couples with a youngest child 18 years of age or older, and in couples with a partner whose labour supply is 'fixed'.

\footnotetext{
${ }^{12}$ The results are for individuals whose labour supply is determined within the model only, so excluding the 'fixed' labour supply by partners in couples that are e.g. disabled, self-employed, etc.

${ }^{13}$ Due to the smaller tax base in the higher brackets than the lower brackets, the percentage point decrease in the tax rate in the higher brackets is larger than in the lower brackets. Specifically, the decrease in the tax rate is respectively: $0.8,2.1,3.4$ and 5.2 percentage points.
} 
Table 11.2 Changes in tax bracket rates

\begin{tabular}{|c|c|c|c|c|c|}
\hline \multirow[b]{2}{*}{ Simulation } & \multirow[b]{2}{*}{ Base } & (1) & (2) & (3) & (4) \\
\hline & & $\begin{array}{l}\text { First } \\
\text { bracket }\end{array}$ & $\begin{array}{l}\text { Second } \\
\text { bracket }\end{array}$ & $\begin{array}{l}\text { Third } \\
\text { bracket }\end{array}$ & $\begin{array}{l}\text { Fourth } \\
\text { bracket }\end{array}$ \\
\hline Change in bracket rate & & -0.8 & -2.1 & -3.4 & -5.2 \\
\hline Ex ante impulse (in billion) & & 1.5 & 1.5 & 1.5 & 1.5 \\
\hline \multicolumn{6}{|l|}{ Percentage changes } \\
\hline Gini coefficient ${ }^{\mathrm{a}}$ & & -0.22 & 0.30 & 0.87 & 1.33 \\
\hline Hours worked per week & 27.5 & -0.02 & 0.09 & 0.07 & 0.02 \\
\hline - Men in couples young. child $0-17$ & 35.2 & -0.09 & 0.04 & 0.10 & 0.07 \\
\hline - Women in couples young. child $0-17$ & 17.8 & 0.12 & 0.17 & -0.03 & -0.10 \\
\hline - Men in other couples & 34.6 & -0.03 & 0.06 & 0.11 & 0.05 \\
\hline - Women in other couples & 20.5 & -0.01 & 0.06 & 0.01 & -0.02 \\
\hline - Single parents young. child $0-17$ & 20.8 & -0.06 & 0.24 & 0.17 & 0.05 \\
\hline - Singles & 30.3 & -0.01 & 0.10 & 0.07 & 0.01 \\
\hline Participation rate & 0.82 & 0.00 & 0.04 & 0.00 & -0.02 \\
\hline - Men in couples young. child $0-17$ & 0.93 & -0.05 & 0.05 & 0.03 & -0.02 \\
\hline - Women in couples young. child $0-17$ & 0.77 & 0.11 & -0.02 & -0.16 & -0.12 \\
\hline - Men in other couples & 0.91 & -0.02 & 0.05 & 0.07 & 0.03 \\
\hline - Women in other couples & 0.71 & 0.02 & 0.01 & -0.04 & -0.04 \\
\hline - Single parents young. child $0-17$ & 0.68 & -0.04 & 0.16 & 0.07 & 0.01 \\
\hline - Singles & 0.85 & -0.02 & 0.05 & 0.03 & 0.01 \\
\hline Effective labour units per hour & & -0.01 & -0.02 & 0.03 & 0.03 \\
\hline
\end{tabular}

${ }^{\mathrm{a}}$ Gini coefficient of disposable household income, using equivalence scales. The Gini coefficient is calculated over the full Dutch adult population with gross income above $66 \%$ of the annual minimum wage

- 'Single parents youngest child $0-17$ ' are single parents with a youngest $0-17$ years of age.

- 'Singles' consists of singles without children, single parents with a youngest child 18 years of age or older, and adult children living with their parents.

For these groups we report the effects on hours worked per week and on the participation rate. We also report the effect on average 'effective labour units per hour', which is calculated as the change in labour costs minus the change in hours worked. The latter captures a composition effect on labour productivity. When workers with low labour costs work less hours and workers with high labour costs work more hours, effective labour units per hour will increase.

Column (1) gives the results for the decrease in the tax rate in the first bracket. Overall, we find hardly any effect of changing the tax rate in the first bracket on hours worked, the participation rate and effective labour units per hour. However, this is the net result of some groups that decrease their labour supply, and some that increase their labour supply. For men in couples, the first bracket is typically inframarginal (not the relevant marginal tax rate), and changing the first bracket rate only generates an income effect. They reduce their labour supply. Women in 
couples with dependent children raise their labour supply. They typically have lower income and lowering the tax rate in the first tax bracket has both an income and a substitution effect. The substitution effect dominates and they increase their labour supply. For women in other couples and singles, the effect on labour supply is close to zero. Single parents show a negative response to the increase in the tax rate in the first tax bracket. A lower first bracket rate increases welfare benefits and as a result single parents reduce their labour supply. Income inequality, as measured by the Gini-coefficient, falls.

Column (2) gives the effect of lowering the tax rate in the second bracket. The effect on overall labour supply in hours is positive, but the effect on labour supply in persons is close to zero, and the effect on effective labour units per hour is slightly negative. For many workers, the second tax bracket is the relevant marginal rate, and their substitution effect dominates their income effect. The same is true for singles. The effect on hours worked by single parents is now also positive, as the lower second tax bracket rate does not increase welfare benefits. Note that the participation rate of women in couples with a child 0-17 years of age decreases. Here the cross effect of higher income for males in these couples plays an important role. This 'income effect' stimulates some women in these couples to leave the labour market, an 'added worker effect' (Lundberg, 1985). Income inequality rises somewhat in this simulation.

Column (3) gives the effects of the decrease in the third tax bracket rate. The increase in overall labour supply in hours is somewhat smaller than in column (2), because the labour supply of women in couples with children falls. Indeed, although for part of these women the third tax bracket is the relevant marginal tax bracket, their own income effect and the income effect from higher income of the male dominates. However, in contrast to column (2), effective labour units per hour increases somewhat. More productive workers increase their hours worked, whereas less productive workers reduce their hours worked.

Finally, column (4) gives the effects of the decrease in the fourth tax bracket. Lowering the fourth tax bracket has only a small positive effect on overall hours worked and the effect on labour supply in persons is even negative (due to the added worker effect). However, effective labour units per hour again increases under in this simulation, due to the composition effect. This simulation generates the largest increase in income inequality.

Overall, changes in marginal tax rates generate rather small effects on the participation rate and hours worked. Indeed, marginal tax rates affect mostly the intensive margin, which is rather unresponsive, and cross-effects in couples also limit the overall effect. Chapter 4 by in 't Veld et al. presents larger labour supply responses from changes in general taxation. However in Chapter 4 the overall labour supply elasticity is calibrated to be $0.3-0.4$. This elasticity is relatively high compared to our estimates, especially for men, and ignores the presence of crosseffects in couples. We should note though that we only model changes in labour participation and hours worked. We do not model changes in e.g. human capital accumulation and retirement. Accounting for these additional changes may result in a larger overall response of effective labour supply to tax changes. 


\subsubsection{Changes in Income Support for Low-Income Households}

More pronounced are the effects of changes in income support targeted at lowincome households. Indeed, these policies implicitly target the more responsive extensive margin, because they provide more subsidies to households where one or more individuals do not work. Table 11.3 gives the simulation results of three cuts in income support for low-income households.

Column (1) gives the effects of a decrease in the subsidy for low-income households with young children (Kindgebonden Budget in Dutch), of 500 million euro in total. ${ }^{14}$ This causes a relatively large increase in labour supply in hours and in persons. In this reform, the income effect and the substitution effect work in the same direction. Furthermore, this stimulates secondary earners and single parents to work (more), which is a relatively elastic group. ${ }^{15}$ However, this reform also reduces effective labour units per hour somewhat, and leads to a substantial rise in income inequality. ${ }^{16}$

In column (2) we simulate a reduction in the rent subsidy for low-income households (Huurtoeslag in Dutch), again for a total amount of 500 million euro. ${ }^{17}$ This also has a relatively strong effect on labour participation, in persons and in hours. However, the effect is less pronounced than in column (1) because it does not solely target the elastic group of households with young children.

Finally, column (3) gives the results for a reduction in the health care subsidy for low-income households (Zorgtoeslag in Dutch), again for a total amount of 500 million euro. ${ }^{18}$ This reform also stimulates labour participation, but the effect is less pronounced than in columns (1) and (2). The health care subsidy is phased out rather gradually, and as a result benefits a large part of the income distribution. Because this subsidy is less targeted at the lowest incomes, reducing it has a more moderate effect on labour supply.

\subsubsection{Changes in Policies Targeted at the Extensive Margin}

Next, we consider policy reforms that explicitly target the extensive margin: changes in welfare benefits and changes in the general in-work tax credit (Arbeidskorting in Dutch).

\footnotetext{
${ }^{14} \mathrm{We}$ decrease the maximum amount for all families by $45 \%$, and keep the phase out rate fixed at $6.75 \%$.

${ }^{15}$ Note that there is also a small effect on men and women in other couples, these are the men and women in couples with a partner whose labour supply is fixed, but have a dependent child.

${ }^{16}$ Note that the budgetary impulse in this simulation is only a third of the tax bracket simulations.

${ }^{17} \mathrm{We}$ reduce the rent benefit by $18 \%$, but keep the phase-out range the same.

${ }^{18} \mathrm{We}$ decrease the maximum amount of the benefit by $14 \%$, and keep the phase out rate at $13.4 \%$.
} 
Table 11.3 Changes in income support for low-income households

\begin{tabular}{|c|c|c|c|}
\hline & (1) & (2) & (3) \\
\hline Simulation & $\begin{array}{l}\text { Income-dependent } \\
\text { child subsidy }^{\mathrm{a}}\end{array}$ & $\begin{array}{l}\text { Income-dependent } \\
\text { rent subsidy }\end{array}$ & $\begin{array}{l}\text { Income-dependent } \\
\text { health care subsidy }\end{array}$ \\
\hline Ex ante impulse (in billion euro) & -0.5 & -0.5 & -0.5 \\
\hline \multicolumn{4}{|l|}{ Percentage changes } \\
\hline Gini coefficient $^{\mathrm{d}}$ & 0.44 & 0.67 & 0.46 \\
\hline Hours worked per week & 0.25 & 0.17 & 0.12 \\
\hline $\begin{array}{l}\text { - Men in couples young. } \\
\text { child } 0-17\end{array}$ & 0.48 & 0.20 & 0.14 \\
\hline $\begin{array}{l}\text { - Women in couples young. } \\
\text { child } 0-17\end{array}$ & 0.86 & 0.15 & 0.19 \\
\hline - Men in other couples & 0.04 & 0.07 & 0.10 \\
\hline - Women in other couples & 0.17 & 0.08 & 0.16 \\
\hline $\begin{array}{l}\text { - Single parents young. } \\
\text { child } 0-17\end{array}$ & 0.76 & 0.72 & 0.20 \\
\hline - Singles & 0.00 & 0.22 & 0.08 \\
\hline Participation rate & 0.22 & 0.15 & 0.11 \\
\hline $\begin{array}{l}\text { - Men in couples young. } \\
\text { child } 0-17\end{array}$ & 0.42 & 0.19 & 0.13 \\
\hline $\begin{array}{l}\text { - Women in couples young. } \\
\text { child } 0-17\end{array}$ & 0.63 & 0.14 & 0.16 \\
\hline - Men in other couples & 0.04 & 0.06 & 0.09 \\
\hline - Women in other couples & 0.14 & 0.07 & 0.14 \\
\hline $\begin{array}{l}\text { - Single parents young. } \\
\text { child } 0-17\end{array}$ & 0.59 & 0.53 & 0.14 \\
\hline - Singles & 0.00 & 0.18 & 0.05 \\
\hline Effective labour units per hour & -0.04 & -0.04 & -0.02 \\
\hline
\end{tabular}

${ }^{\mathrm{a}} \mathrm{A}$ decrease in the income dependent child benefit (Kindgebonden Budget), an income dependent subsidy for parents with a youngest child up to 18 years of age. The subsidy is phased-out from 19,463 euro at a rate of $6.75 \%$. We decrease the subsidy by $45 \%$, and keep the phase-out rate the same. Hence, we extend the phase-out range of the subsidy

${ }^{\mathrm{b}}$ A decrease in the income dependent rent subsidy (Huurtoeslag), an income dependent subsidy that compensates lower income households for rent costs. It depends on household income, household composition and the rent level. The maximum amount in 2015 is 4079 euro for single-person households and 3759 euro for multi-person households. We lower the rent benefit by $18 \%$ but keep the phase-out range the same

${ }^{\mathrm{c}}$ A decrease in the income dependent health care subsidy (Zorgtoeslag), an income dependent subsidy that compensates lower income households for the compulsory health care insurance. In 2015, the maximum health care benefit is 936 euro for singles and 1788 euro for couples. This benefit is phased out from 19,463 euro at a rate of $13.4 \%$ in 2015 . We lower the health care benefit by $14 \%$ but keep the phase-out range the same

${ }^{\mathrm{d}}$ Gini coefficient of disposable household income, using equivalence scales. The Gini coefficient is calculated over the full Dutch adult population with gross income above $66 \%$ of the annual minimum wage 
Table 11.4 Changes in policies targeted at the extensive margin

\begin{tabular}{|c|c|c|c|}
\hline & $(1)$ & $(2)$ & (3) \\
\hline Simulation & $\begin{array}{l}\text { Welfare } \\
\text { benefits }^{\mathrm{a}}\end{array}$ & $\begin{array}{l}\text { In-work tax credit, } \\
\text { across-the-board }^{\text {b }}\end{array}$ & $\begin{array}{l}\text { In-work tax credit, } \\
\text { targeted at low incomes }\end{array}$ \\
\hline Ex ante impulse (in billion euro) & -0.5 & 1.5 & 1.5 \\
\hline \multicolumn{4}{|l|}{ Percentage changes } \\
\hline Gini coefficient $^{\mathrm{d}}$ & 0.78 & 0.10 & -0.35 \\
\hline Hours worked per week & 0.66 & 0.13 & 0.17 \\
\hline $\begin{array}{l}\text { - Men in couples young. } \\
\text { child } 0-17\end{array}$ & 0.67 & 0.03 & -0.04 \\
\hline $\begin{array}{l}\text { - Women in couples young. } \\
\text { child } 0-17\end{array}$ & 0.54 & 0.33 & 0.61 \\
\hline - Men in other couples & 0.47 & 0.10 & 0.02 \\
\hline - Women in other couples & 0.62 & 0.15 & 0.23 \\
\hline $\begin{array}{l}\text { - Single parents young. } \\
\text { child } 0-17\end{array}$ & 2.54 & 0.33 & 0.53 \\
\hline - Singles & 0.67 & 0.14 & 0.20 \\
\hline Participation rate & 0.62 & 0.13 & 0.22 \\
\hline $\begin{array}{l}\text { - Men in couples young. } \\
\text { child } 0-17\end{array}$ & 0.67 & 0.09 & 0.13 \\
\hline $\begin{array}{l}\text { - Women in couples young. } \\
\text { child } 0-17\end{array}$ & 0.49 & 0.20 & 0.50 \\
\hline - Men in other couples & 0.43 & 0.11 & 0.07 \\
\hline - Women in other couples & 0.57 & 0.14 & 0.27 \\
\hline $\begin{array}{l}\text { - Single parents young. } \\
\text { child } 0-17\end{array}$ & 2.38 & 0.32 & 0.60 \\
\hline - Singles & 0.60 & 0.09 & 0.15 \\
\hline Effective labour units per hour & -0.12 & -0.05 & -0.10 \\
\hline
\end{tabular}

${ }^{\text {a }}$ Reduction in welfare benefits by $14 \%$

${ }^{\mathrm{b}}$ An increase in the (maximum) general in-work tax credit (Arbeidskorting) of 245 euro, by increasing the phase-in rate from 19.7 to $22.0 \%$

${ }^{\mathrm{c}}$ An increase in the (maximum) general in-work tax credit (Arbeidskorting) of 441 euro, by increasing the phase-in rate from 19.7 to $23.9 \%$. The higher in-work tax credit is phased out from 34,000 euro onwards at $4 \%$. The phase-out rate is the same as in the current system, but the new phase-out starts at an income of 34,000 euro instead of 49,770 euro in the current system. The level of the general in-work tax credit for incomes above 49,770 euro remains the same as in the current system

${ }^{\mathrm{d}}$ Gini coefficient of disposable household income, using equivalence scales. The Gini coefficient is calculated over the full Dutch adult population with gross income above $66 \%$ of the annual minimum wage

In the first simulation, column (1) of Table 11.4, we lower welfare benefits by $14 \%$ for a total amount of 500 million euro. This leads to a substantial increase in overall labour supply in hours and persons. The response is particularly large for single parents, $32 \%$ of single parents are on welfare benefits in the base, and they are also particularly responsive to financial incentives. The effect on effective 
labour units per hour is negative, as the productivity of the additional workers is below average. Also, lowering welfare benefits leads to a substantial rise in income inequality.

In the second and third simulation we use the 'carrot' rather than the 'stick', and increase the general in-work tax credit, for all workers, for a total amount of 1.5 billion euro. ${ }^{19}$ In column (2), we increase the maximum level of the tax credit by 245 euro, such that the maximum tax credit (2465 euro) is reached at the same income of 19,463 euro. The effects are much smaller than in the first simulation, despite the larger budgetary impulse, because the share of employed individuals is much larger than the share of individuals on welfare benefits. This makes the increase in disposable income per working person much smaller than the reduction in disposable income of non-working individuals in the welfare benefits simulation (in absolute terms). Also, this reform is less targeted at the responsive group of single parents. Still, labour supply in hours and persons increases for all groups, and the effects are larger than for the reductions in the tax bracket rates. There is some decrease in effective labour units per hour and a slight increase in income inequality.

In column (3) we target the in-work tax credit more strongly at low income individuals by raising the maximum tax credit even further (to 2661 euro). In order to keep the budgetary impulse identical to the second scenario, we lower the start of the phase out of the tax credit to an income of 34,000 euro. This leads to a larger effect on total hours worked because the tax credit is more targeted at the extensive margin. The higher tax credit now increases labour supply more for women in couples, singles and single parents, than in the second simulation. By contrast, men in couples with dependent children slightly lower their labour supply. Some men, with a high income, now receive a lower tax credit due to the earlier phase out of the tax credit. Effective labour units per hour decreases more in column (3) than in column (2). However, reform (3) decreases rather than increases income inequality.

\subsubsection{Changes in Policies Targeted at Working Parents with Children}

Table 11.5 gives the results for policies targeted at working parents with children. This group is of particular interest because there are many policies targeted specifically at this group, and because mothers with young children appear to be particularly responsive to changes in financial incentives. We consider simulations with a budgetary impulse of 500 million euro, because these policies target only a subgroup of the working age population (and therefore the budgetary base is relatively small).

\footnotetext{
${ }^{19}$ In 2015 , the general in-work tax credit rises up to an income of 19,463 euro (close to the minimum wage), where the maximum credit is 2220 euro. The tax credit is phased-out with $4 \%$, over an income of 49,770 euro and 100,670 euro.
} 
Table 11.5 Changes in policies for working parents with children

\begin{tabular}{|c|c|c|c|c|}
\hline & $(1)$ & (2) & (3) & (4) \\
\hline Simulation & $\begin{array}{l}\text { credit }^{\mathrm{a}} \\
\text { credit }^{\mathrm{a}}\end{array}$ & $\begin{array}{l}\text { Additional } \\
\text { combination } \\
\text { credit }^{\text {b }}\end{array}$ & $\begin{array}{l}\text { Income } \\
\text { dependent } \\
\text { combination } \\
\text { credit }^{c}\end{array}$ & $\begin{array}{l}\text { Childcare } \\
\text { subsidies }^{\mathrm{d}}\end{array}$ \\
\hline Ex ante impulse (in billion euro) & 0.5 & 0.5 & 0.5 & 0.5 \\
\hline \multicolumn{5}{|l|}{ Percentage changes } \\
\hline Gini coefficient ${ }^{\mathrm{e}}$ & -0.11 & -0.10 & -0.01 & 0.01 \\
\hline Hours worked per week & 0.05 & 0.11 & 0.18 & 0.11 \\
\hline - Men in couples young. child $0-17$ & 0.03 & 0.02 & 0.02 & 0.04 \\
\hline - Women in couples young. child $0-17$ & 0.25 & 0.72 & 1.25 & 0.92 \\
\hline - Men in other couples & 0.01 & 0.00 & 0.00 & 0.00 \\
\hline - Women in other couples & 0.03 & 0.05 & 0.06 & 0.00 \\
\hline $\begin{array}{l}\text { - Single parents young. child } 0-17 \\
\end{array}$ & 0.39 & 0.76 & 1.10 & 0.12 \\
\hline - Singles & 0.00 & 0.00 & 0.00 & 0.00 \\
\hline Participation rate & 0.10 & 0.19 & 0.16 & 0.08 \\
\hline - Men in couples young. child $0-17$ & 0.09 & 0.10 & 0.10 & 0.05 \\
\hline - Women in couples young. child $0-17$ & 0.39 & 0.91 & 0.66 & 0.47 \\
\hline - Men in other couples & 0.01 & 0.00 & 0.00 & 0.00 \\
\hline - Women in other couples & 0.04 & 0.07 & 0.06 & 0.00 \\
\hline $\begin{array}{l}\text { - Single parents young. child } 0-17 \\
\end{array}$ & 0.40 & 0.77 & 0.99 & 0.10 \\
\hline - Singles & 0.00 & 0.00 & 0.00 & 0.00 \\
\hline Effective labour units per hour & -0.02 & -0.04 & -0.05 & -0.02 \\
\hline Hours formal childcare & 0.95 & 1.66 & 2.12 & 8.76 \\
\hline
\end{tabular}

${ }^{\text {a }}$ The combination credit (Combinatiekorting) is a flat tax credit for working parents, with gross income above 4857 euro, with a youngest child up to 12 years of age. We set the credit at 270 euro per person

${ }^{\mathrm{b}}$ The additional combination credit (Aanvullende Combinatiekorting) is a flat tax credit for working secondary earners and working single parents, with gross income above 4857 euro, with a youngest child up to 12 years of age. We set the credit at 600 euro per person

${ }^{\mathrm{c}}$ The income dependent combination credit (Inkomensafhankelijke Combinatiekorting) is a tax credit for working secondary earners and working single parents with a youngest child up to 12 years of age. The tax credit is income dependent, we increase the phase-in rate from 4 to $8 \%$. The phase-in range runs from 4857 euro to 32,832 euro, at which the maximum credit increases by 1109 euro. The tax credit is not phased out

${ }^{\mathrm{d}}$ An increase in childcare subsidies (Kinderopvangtoeslag). Families only qualify for childcare subsidies when both parents work. The change in childcare subsidies is set in such a way that there is a proportional decline in the parental contribution rate. Because higher incomes have a higher parental contribution rate, this benefits more the parents with a higher income

${ }^{\mathrm{e}}$ Gini coefficient of disposable household income, using equivalence scales. The Gini coefficient is calculated over the full Dutch adult population with gross income above $66 \%$ of the annual minimum wage 
First, in column (1), we simulate the reintroduction of an in-work tax credit for working parents with a youngest child up to 12 years of age (Combinatiekorting in Dutch). ${ }^{20,21}$ This has a positive effect on labour supply. However, the effect on labour supply is limited because a large part goes to primary earners in couples, mostly men, who are rather unresponsive to financial incentives.

Next, in column (2), we increase the in-work tax credit for secondary earners and single parents with a youngest child up to 12 years of age (Aanvullende Combinatiekorting in Dutch). ${ }^{22}$ Primary earners do not receive this tax-credit. Therefore, the increase in labour supply is much larger, because it targets the responsive groups of secondary earners and single parents (typically women) with young children. These groups are rather responsive to changes in financial incentives.

The reform in column (3) is even more effective in terms of labour supply. In this simulation we increase the income dependent part of the income dependent tax credit for secondary earners and single parents with a youngest child up to 12 years of age (Inkomensafhankelijke Combinatiekorting in Dutch). ${ }^{23}$ The number of hours worked increases more than in column (2). The reform in column (3) not only makes working more attractive, but also encourages secondary earners and single parents to work more days per week.

Finally, we consider the effect of increasing childcare subsidies in column (4). We consider a proportional decrease (of 38\%) across incomes in the parental fee that results after deducting the subsidy from the full hourly price. This reform not only targets secondary earners and single parents with a youngest child up to 12 years of age, but also primary earners with children. Again, there is a substantial increase in hours worked. However, the effects on labour supply in hours and persons are smaller than in column (3). Indeed, the childcare reform reduces the effective hourly child care price for parents. This leads to a large increase in the use of formal childcare, see the last row in the table, which leads to substantial additional budgetary costs (which are included in the 500 million euro of the impulse). This makes this reform less effective per additional euro spent than the increase in the income dependent tax credit for working parents with a young child.

\footnotetext{
${ }^{20}$ This tax credit was replaced by an income-dependent tax credit which we consider below.

${ }^{21}$ We reintroduce a tax credit of 270 euro for individuals earning at least 4,857 euro in the targeted group.

${ }^{22}$ We reintroduce a tax credit of 600 euro for individuals earning at least 4,857 euro in the targeted group.

${ }^{23}$ We increase the phase-in rate of 4 percentage points and increase the maximum credit by 1109 euro.
} 
Table 11.6 Reform package of the Tax Plan 2016

\begin{tabular}{l|c}
\hline Simulation & Tax Plan $2016^{\mathrm{a}}$ \\
\hline Ex-ante impulse (in billion euro) & 5.0 \\
\hline & Percentage changes \\
\hline Gini coefficient & 0.30 \\
\hline Hours worked per week & 0.47 \\
\hline - Men in couples youngest child 0-17 & -0.01 \\
\hline - Women in couples youngest child 0-17 & 2.27 \\
\hline - Men in other couples & 0.03 \\
\hline - Women in other couples & 0.53 \\
\hline - Single parents youngest child 0-17 & 1.08 \\
\hline - Singles & 0.45 \\
\hline Participation rate & 0.56 \\
\hline - Men in couples youngest child 0-17 & 0.27 \\
\hline - Women in couples youngest child 0-17 & 1.59 \\
\hline - Men in other couples & 0.12 \\
\hline - Women in other couples & 0.68 \\
\hline - Single parents youngest child $0-17$ & 1.17 \\
\hline - Singles & 0.38 \\
\hline Effective labour units per hour & -0.18 \\
\hline
\end{tabular}

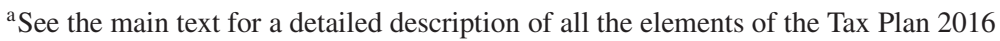

\subsubsection{Tax Plan 2016}

Finally, Table 11.6 gives the simulation results of the Tax Plan 2016 of the Dutch government, debated extensively in Dutch parliament. The Tax Plan 2016 reduces income taxation by 5 billion euros. The main goal of this reform was to create more employment (Ministry of Finance, 2015a,b). We first discuss the elements of The Tax Plan 2016, and subsequently discuss the simulation results.

The Tax Plan 2016 consists of the following elements:

- An increase in the in-work tax credit, targeted at low-income workers $(+2.5$ billion euros). ${ }^{24}$

- A reduction in the second and third tax bracket rate of 2.1 percentage points $(+2.7$ billion euros).

- An increase in the start of the fourth tax bracket by 8000 euros $(+0.9$ billion euros).

\footnotetext{
${ }^{24}$ Here, the maximum level of the in-work tax credit is increased with 665 euros. The phase-out
} now starts at an income of 33,000 euros instead of 49,895 euros. 
- An increase in the income-dependent combination credit for working parents with a youngest child of up to 12 years of age ( +0.25 billion euros $){ }^{25}$

- An increase in the childcare subsidy so that the parental contribution decreases by $38 \%$ ( +0.25 billion euros).

- The introduction of a wage cost subsidy for employers (+0.5 billion euros). ${ }^{26}$

- The general tax credit is phased out completely for higher incomes ( -2.1 billion euros). ${ }^{27}$ This increases the effective marginal tax rate for this group.

The simulation results in Table 11.6 show that this reform increases labour supply in persons and hours worked, by $0.6 \%$ and $0.5 \%$, respectively. The increase in labour supply is relatively strong for single parents and women in couples with young children. The Tax Plan 2016 includes a number of reforms that are relatively effective in stimulating labour supply, such as the targeted in-work tax credit for workers with a relatively low income, the income-dependent combination credit and childcare subsidies. The reform however also reduces effective labour units per hour and increases income inequality to some extent.

\subsection{Discussion and Conclusion}

In this chapter we show how the behavioural responses to changes in financial incentives can be estimated and used in the analysis of tax-benefit reforms, using structural models of labour supply. A very large administrative dataset allows us to uncover the behavioural responses for a large number of subgroups on the Dutch labour market. We find large differences in the responses to financial incentives. On the one hand, singles and men in couples are rather unresponsive to changes in financial incentives. On the other hand, single parents are women in couples with young children are relatively responsive. We also find that most of the response is in the participation rate (the extensive margin), the response in hours worked per week per employed (the intensive margin) is much smaller. We further find cross effects for women in couples that are non-negligible; when the income of the husband increases, the women work less hours.

\footnotetext{
${ }^{25}$ The maximum amount of this credit increases by 500 euros, by increasing the phase-in rate from $4.0 \%$ to $5.8 \%$.

${ }^{26}$ Employers receive a subsidy of 2000 euros (for a full-time position) for employees with an hourly wage below $110 \%$ of the minimum wage. For employees with an hourly wage of between $110 \%$ and $120 \%$ of the minimum wage, the maximum subsidy is 1000 euros. For employees working part-time, the wage cost subsidy is lowered proportionally. We do not explicitly model the employer side. In the simulation we assume that the wage cost subsidy is fully shifted onto workers, consistent with findings in e.g. Melguizo and Gonzalez-Paramo (2013). This seems particularly likely in a small open economy such as that of the Netherlands, where capital is close to infinitely elastic to labour costs and labour is much less elastic to net wages.

${ }^{27}$ The phase-out rate increases from $3.32 \%$ to $4.80 \%$.
} 
These findings have important implications for tax-benefit reforms. Reductions in tax bracket rates are relatively ineffective in stimulating labour supply, because intensive margin responses are relatively small. Furthermore, for reductions in the third and fourth tax bracket, the cross-effect on women's labour supply in couples also mitigates the effect on hours worked. Reductions in income support for lowincome households are relatively effective in stimulating labour supply, because they target the more elastic extensive margin. However, the downside is an increase in income inequality. On the other hand, increasing in-work benefits for low-income workers is also relatively effective, and can reduce rather than increase income inequality. The most effective in terms of labour supply are tax credits and (child care) subsidies for single parents and secondary earners with young children, as these groups are the most responsive to changes in financial incentives. We also present simulation results for the Tax Plan 2016. The Tax Plan 2016 stimulates labour supply in persons and in hours, and contains a number of policy changes that are relatively effective, such as an increase in the in-work tax credit for low-income workers, an increase in the in-work tax credit for single parents and secondary earners with a young child and child care subsidies.

We conclude by indicating a number of limitations of the analysis. People are assumed to be free in their choice of whether or not to participate, and how many hours to work. In an extension we estimated a so-called double-hurdle model (Cragg, 1971) for involuntary unemployment. The policy simulation results are very similar to the base model (De Boer, 2015) as very few people in the data are classified as involuntary unemployed. ${ }^{28}$ Furthermore, we focus on the labour supply responses to changes in the tax-benefit system, whereas other studies look at a broader range of behavioural responses, by studying the elasticity of taxable income (Saez et al., 2012b). Jongen and Stoel (2013) find that the elasticity of taxable labour income for the average worker is not that different from the labour supply elasticity. But for high-income workers the labour supply elasticity is much lower than the elasticity of taxable income, in line with other studies (Saez et al., 2012b). Therefore, to determine the budgetary consequences of an increase in the top tax rate, we need to consider other behavioural responses next to the labour supply response. We further ignore general equilibrium effects on prices and wages, but this may not be a bad approximation for the long run in a small open economy like the Netherlands (Aaberge and Colombino, 2014). We also ignore the life cycle, accounting for life-cycle effects can be important for the analysis of tax-benefit reform (e.g. Imai and Keane, 2004; Keane, 2011; Blundell et al., 2016). This would be an interesting direction for future research, but requires data on consumption. Finally, recent work by Chetty et al. (2009) shows that informational frictions can play an important role in the behavioural responses to financial incentives. This too seems an interesting direction for future research.

${ }^{28}$ Note that we use data from before the Great Recession, when unemployment was relatively low in the Netherlands. 


\section{References}

Aaberge R, Colombino U (2014) Labour supply models. In: O'Donoghue C (ed) Handbook of microsimulation modelling. Emerald, Bingley, pp 167-222

Aaberge R, Dagsvik J, Strom S (1995) Labor supply responses and welfare effects of tax reforms. Scand J Econ 97(4):635-659

Aaberge R, Colombino U, Strom S (1999) Labour supply in Italy: an empirical analysis of joint household decisions, with taxes and quantity constraints. Appl Econ 14(4):403-422

Bargain O, Orsini K, Peichl A (2014) Comparing labor supply elasticities in Europe and the United States: new results. J Hum Resour 49(3):723-838

Bettendorf L, Folmer K, Jongen E (2014) The dog that did not bark: the EITC for single mothers in the Netherlands. J Public Econ 119:49-60

Bettendorf L, Jongen E, Muller P (2015) Childcare subsidies and labour supply - evidence from a large Dutch reform. Labour Econ 36:112-123

Blau D, Kahn L (2007) Changes in the labor supply behavior of married women: 1980-2000. J Labor Econ 25(3):393-438

Blundell R, Costa-Dias M, Meghir C, Shaw J (2016) Female labour supply, human capital and welfare reform. Econometrica 84(5):1705-1763

Bosch N, Jongen E (2013) Intensive margin responses when workers are free the choose: evidence from a Dutch tax reform. Paper presented at EALE 2013

Bosch N, van der Klaauw B (2012) Analyzing female labor supply - evidence from a Dutch tax reform. Labour Econ 19:271-280

Brewer M, Duncan A, Shephard A, Suarez M (2006) Did the working families' tax credit work? The impact of in-work support on labour supply in Great Britain. Labour Econ 13:699-720

Chetty R (2009) Is the taxable income elasticity sufficient to calculate deadweight loss? The implications of evasion and avoidance. Am Econ J Econ Pol 1(2):31-52

Chetty R, Looney A, Kroft K (2009) Salience and taxation: theory and evidence. Am Econ Rev 99(4):1145-1177

CPB (2015) Kansrijk Arbeidsmarktbeleid. CPB Netherlands Bureau for Economic Policy Analysis, The Hague

Cragg J (1971) Some statistical models for limited dependent variables with applications to the demand for durable goods. Econometrica 39:829-844

De Boer HW (2015) A structural analysis of labour supply and involuntary unemployment in the Netherlands. CPB Discussion Paper 312, The Hague

De Boer H, Jongen E (2017) The best of both worlds - analysing tax-benefit reforms using structural models and natural experiments. mimeo, CPB, The Hague

De Boer HW, Jongen E, Kabatek J (2015) The effectiveness of fiscal stimuli for working parents. IZA Discussion Paper 9298, Bonn

Heckman J, Singer B (1984) A method for minimizing the impact of distributional assumptions in econometric models for duration data. Econometrica 52:271-320

Imai S, Keane M (2004) Intertemporal labor supply and human capital accumulation. Int Econ Rev 45(2):601-641

Jongen E, Stoel M (2013) Estimating the elasticity of taxable labour income in the Netherlands. CPB Background Document, The Hague

Jongen E, De Boer H, Dekker P (2014) MICSIM: a behavioural microsimulation model for the analysis of tax-benefit reform in the Netherlands. CPB Background Document, The Hague

Keane M (2011) Labor supply and taxes: a survey. J Econ Lit 49(4):961-1075

Keane M, Moffitt R (1998) A structural model of multiple welfare program participation and labor supply. Int Econ Rev 39(3):553-589

Koot P, Vlekke M, Berkhout E, Euwals R (2016) MIMOSI: microsimulatiemodel voor belastingen, sociale zekerheid, loonkosten en koopkracht. CPB Background Document, The Hague

Lundberg S (1985) The added worker effect. J Labor Econ 3(1):11-37 
Mastrogiacomo M, Bosch N, Gielen M, Jongen E (2017) Heterogeneity in labour supply responses: evidence from a major tax reform. Oxf Bull Econ Stat 79:769-796

McFadden D (1978) Modeling the choice of residential location. In: Karlqvist A, Lundqvist L, Snickars F, Weibull J (eds) Spatial interaction theory and planning models. North-Holland, Amsterdam, pp 75-96

Melguizo A, Gonzalez-Paramo J (2013) Who bears labour taxes and social contributions? A metaanalysis approach. SERIEs 4:247-271

Ministry of Finance (2015a) 4e nota van wijziging belastingplan. Ministry of Finance, The Hague Ministry of Finance (2015b) Belastingherziening. Ministry of Finance, The Hague

Mirrlees J (1971) An exploration in the theory of optimum income taxation. Rev Econ Stud 38(2):175-208

Saez E, Slemrod J, Giertz S (2012a) The elasticity of taxable income with respect to marginal tax rates: a critical review. J Econ Lit 50(1):3-50

Saez E, Slemrod J, Giertz S (2012b) The elasticity of taxable income with respect to marginal tax rates: a critical review. J. Econ Lit 50(1):3-50

Statistics Netherlands (2012) Documentatierapport Arbeidsmarktpanel 1999-2009V1. Statistics Netherlands, Leidschenveen, http://www.cbs.nl/NR/rdonlyres/672F45FE-2BA8-41D7-81EA37D2B40FBF1D/0/arbeidsmarktpanelmicrodata.pdf

Train K (2008) EM algorithms for nonparametric estimation of mixing distributions. J Choice Modell 1:40-69

Van Soest A (1995) Structural models of family labor supply: a discrete choice approach. J Hum Resour 30(1):63-88 


\title{
Chapter 12 CPB and the Assessment of Structural Reforms
}

\author{
Laura van Geest and Daniel van Vuuren
}

\subsection{Introduction}

CPB Netherlands Bureau for Economic Policy Analysis provides the official economic forecasts on which budgetary policy is based. In addition, it produces policy relevant economic research which is academically up to standard. In fulfilling these tasks, CPB is unique in the world and has attracted attention of policy makers in Europe, particularly for its contribution to evidence-based policy. One of the unique features of CPB is its independent status. The idea of (more) independent economic forecasts is embodied in the Independent Fiscal Institutes (IFIs), which have been established in the Eurozone in the aftermath of the 2012 crisis, in line with EU regulation. The notion that independent assessments can lead towards more competitive economies has led to the Council Recommendation on the establishment of National Productivity Boards (2016), in line with the Five Presidents' Report (2015).

The Dutch experience may provide some inspiration for the establishment of new institutes. We give an overview of CPB's history and describe its mission and daily practice. Specifically in view of the Recommendation on National Productivity

The authors thank Peter van den Berg, Frank den Butter, Massimo Gioliudori, Edwin van de Haar, Johannes Hers, Egbert Jongen, Wim Suyker, and Bas ter Weel for useful comments on an earlier draft of this paper.

L. van Geest $(\square)$

CPB Netherlands Bureau for Policy Analysis, The Hague, The Netherlands

e-mail: L.B.J.van.Geest@cpb.nl

D. van Vuuren

CPB Netherlands Bureau for Policy Analysis, The Hague, The Netherlands

Tilburg University, Tilburg, The Netherlands

(C) Springer International Publishing AG, part of Springer Nature 2018 
Boards, we present some case studies in the area of labour market policies. Finally, we confront our experiences with the legislation present and envisaged at the EU level.

\subsection{A Bird's Eye View of CPB}

This section presents a brief history of CPB and derives some important lessons. In particular, some lessons can be drawn from CPB's inception, its relation with politics, its legal mandate, its position within society, and the kind of analyses it provides.

\subsubsection{Never Waste a Good Crisis}

In the case of $\mathrm{CPB}$, its inception fits the stylized fact that crises can provide impetus to novel approaches in policy. CPB started in 1945 (although it was formally established only in 1947). The Netherlands and its economy had experienced major destruction during World War II. Moreover, the war was proceeded by a deep economic recession in the nineteen thirties. There was thus a clear need to get up to speed with effective and efficient policies to rebuild the Netherlands.

\subsubsection{Water and Oil Don't Mix}

It also fits the stylized fact that fragmented political systems favour neutral, third parties or referees. Even after the war, Dutch politics remained 'pillarized' or fragmented. Dutch election results inevitably led to coalition governments, as no single party was ever able to muster a majority in parliament. Under those circumstances, an independent institute is more attractive than an institute that might just speak his master's voice. Unbiased forecasts provided by institutions under a political umbrella are highly unusual. In the Netherlands, independent forecasts and analysis provide a common denominator for the political debate between parties. The non-partisan role of the CPB led to a clear division of labour between analysis and modelling on the one hand, and policy choices and judgment on the other hand. CPB focuses on positive analysis, i.e., the state of the economy (forecasts) and effective policy instruments for a broad range of topics. Rather than discussing or advising on the desirability of certain policy goals, CPB concentrates on the trade-offs between these goals. Policy advice is the purview of the Social Economic Council, in which social partners as well as civil society, academia, the central bank and CPB are represented. 


\subsubsection{With a Little Help from My Friends}

In terms of legal mandate and positioning, CPB started off as a typical Dutch (informal) organization. The formal mandate of $\mathrm{CPB}$ was quite vague. The law established CPB and required it to contribute to the Central Economic Plan (CEP). Even though CPB still publishes a CEP every year, the document has little to do with formal economic planning. It rather presents one of the four forecasts that CPB publishes every year. While organizationally CPB is part of the Ministry of Economic Affairs, it operates independently. It was only in 2012 that this tradition was formalized through secondary legislation, which explicitly states that CPB cannot receive instructions from politicians or civil servants and determines its own work program. In 2013, the government legally formalized the role of CPB as independent forecaster for the budgetary process, in response to the requirements of the Fiscal Compact and the Two Pack. However, in line with the existing view on the proper division of labour between forecasting and policy analysis on the one hand, and policy decisions on the other, the Dutch government allocated the normative part of the mandate of an Independent Fiscal Institute to the Council of State. The Council of State has a strong reputation in the area of independent policy advice, while close cooperation on the basis of a clear division of labour between these two bodies prevents double work and bureaucracy. In 2017, the CPB was designated as the National Productivity Board.

CPB receives a budget from the Ministry of Economic Affairs, but this budget can be supplemented from other official sources up to a maximum of $20 \%$. Presently, CPB employs around 115 full time equivalent staff. The Director is a civil servant, appointed for a non-renewable 7-year period by the Council of Ministers. The Director decides on the annual work program of CPB.

While the focus of CPB remained broadly unchanged, political developments, new technologies, new economic insights and novel policy questions all left their mark on the work of CPB over the decades.

\subsubsection{Rome Was Not Built in a Day}

Initially, CPB had some difficulty to find its voice, as most political parties and employers' organizations had little sympathy for 'the planning of the economy' (Passenier 1994). As member of the Social and Economic Council, CPB gradually found a way to contribute to the decentralized Dutch polder model of decisionmaking. While the polder model seems to be on the wane, CPB kept its influential position. The practice to analyse election platforms, since 1986, seems a case in point. 


\subsubsection{Panta Rhei}

While CPB's focus remained the same, policy issues and the associated analytical approaches changed over time (Table 12.1). A loosely defined mandate enabled this type of adaptation. Practically, paper and pencil gave way to punched carts and personal computers, allowing for more complex models. Theoretically, existing Keynesian models were complemented with supply side models and short- and medium-term forecasts with long-term projections, also in the form of scenario studies. The macro-economic focus was complemented by micro-economic research on competition and regulatory issues. Cost benefit analyses of individual projects have been undertaken next to studies for the economy at large. Evaluations and micro-econometric research have been added to the portfolio of activities as well. Politically, topics changed over time as well, from rebuilding the Netherlands and the establishment of the welfare state, to lessening labour shortages and later battling high unemployment.

Table 12.1 Major events in the evolution of CPB

\begin{tabular}{l|l}
\hline 1945 & Start of CPB with Tinbergen as its first director \\
\hline 1946 & $\begin{array}{l}\text { Central government budget based on CPB's estimates of the national economy. CPB } \\
\text { starts to provide a regular macroeconomic perspective on Dutch public finance. The } \\
\text { pre-war ideas of social planning gradually evolve into forecasts and analyses of } \\
\text { objectives and tools }\end{array}$ \\
\hline 1950 & Start of Social and Economic Council \\
\hline 1953 & First CPB-macro model for analysing and forecasting the Dutch economy \\
\hline 1961 & $\begin{array}{l}\text { In September each year, simultaneously with the Government Budget, a Macro } \\
\text { Economic Outlook on the Dutch economy is published, including estimates of Dutch } \\
\text { public finance }\end{array}$ \\
\hline 1971 & First advisory group on fiscal policy; CPB is one of the participants \\
\hline 1976 & $\begin{array}{l}\text { Supply side included in macro-model (clay-clay vintage-production function), which } \\
\text { substantially changed policy recommendations }\end{array}$ \\
\hline 1986 & $\begin{array}{l}\text { First analysis of the economic consequences of the election platforms of political } \\
\text { parties }\end{array}$ \\
\hline 1992 & First applied general equilibrium model for the labour market (MIMIC) \\
\hline 1992 & First long-term scenario analysis stressing the role of institutions (Scanning the future) \\
\hline 1993 & $\begin{array}{l}\text { Start of first major study on economic institutions: a comparison of economic } \\
\text { institutions in Germany and the Netherlands }\end{array}$ \\
\hline 1994 & Cost-benefit analysis of railway freight track to Germany (Betuwelijn) \\
\hline 1998 & First analysis of sustainable public finance (generational accounts) \\
\hline 2000 & National guidelines by CPB on cost-benefit analysis \\
\hline 2012 & Secondary legislation confirming Independence CPB \\
\hline 2013 & $\begin{array}{l}\text { CPB (positive analysis) and Council of State (normative analysis) IFI for the } \\
\text { Netherlands }\end{array}$ \\
\hline 2017 & CPB National Productivity Board for the Netherlands \\
\hline & upda of Bos and Teus (2012) \\
\hline
\end{tabular}

Source: update of Bos and Teulings (2012) 


\subsubsection{Bottom Up Is Best}

CPB is a typical Dutch animal, established just after a major crisis, tailored to the Dutch political arena. While the CPB experience can provide useful pointers, it is naïve to think it can be effectively implemented in a completely different political biosphere. Institutes like CPB can only play a role if the public at large is convinced of evidence-based policy. Commitment is not achieved through force but through persuasion, tailored to local circumstances.

\subsection{CPB's Mission: From Theory to Practice}

CPB aims to provide independent, impartial economic analysis that is policy relevant and academically up to standard. How did CPB become and, more importantly, remain a widely trusted source of policy relevant economic analysis, a dependable 'Google translate' between research and policy?

CPB's first director was Jan Tinbergen, front-runner in quantitative economics, who received the Nobel prize in economics in 1969. He was well known and respected, but also modest in outlook. A vocal advocate of a clear division of labour between independent data collection (Statistics Netherlands), independent policy analysis (CPB) and consensus building policy advice (SER), proponent of the delineation between policy instruments and policy goals and well known for his thesis that you cannot have more policy goals than independent instruments. CPB still benefits from its impressive first front man, underscoring that newly established institutes can benefit from prudent early appointments.

CPB strives for neutrality and is perceived as independent and non-partisan. A poll among the public at large shows that $91 \%$ of the respondents recognize CPB's name, with $60 \%$ knowing what CPB stands for; $58 \%$ of the respondents consider $\mathrm{CPB}$ to be objective, while $12 \%$ regards $\mathrm{CPB}$ either left or right leaning (Ipsos 2015).

However, the drive towards neutrality is not straightforward and CPB is not beyond public debate. Firstly, economics is just one of the social sciences and it has taken a hit after the 2008 crisis. Economics as a discipline has a certain perspective on policy issues. Psychologists, lawyers or philosophers might focus on different issues, other instruments and look differently at concepts like trade-offs and the welfare function. Furthermore, economists are more inclined to use figures than scientists from other disciplines, as figures are believed to speak louder than words. Where relevant, CPB enters collaboration with other disciplines, but finding a proper balance remains a challenge.

Secondly, the economics profession is a broad church. There are diverging views and models, both normative and positive. While think tanks often tend to opt for one school of thought or the other, CPB strives for a neutral stance. CPB focuses 
on empirical work and models and approaches, based on the research issue at hand. This will satisfy most, but certainly not all.

Thirdly, CPB operates in a political and public environment. Maintaining a nonpartisan profile requires a clear strategy on the type of work to be undertaken and how to communicate about it. Even then it is not always successful, because parties sometimes confuse the message and the messenger. Most importantly, CPB does not give judgments. It sticks to the presentation of facts and analyses, showing tradeoffs between various policy goals, refraining from choices. It is our firm conviction that facts speak louder than words. The allocation of the normative part of the IFI mandate to a different body than CPB should be seen against this background. CPB's prudent approach means that some questions may remain unanswered in order to avoid a descent into speculation. And when presenting results, the uncertainties should be acknowledged, e.g. through fan charts in forecasts and scenario analyses. As a non-partisan body, we provide bespoke analyses to all parties in parliament (on occasion confidentially), including opposition parties. In general, requests are honoured provided adequate knowledge, time and personnel are available. This also underscores our non-partisan profile.

Becoming a trusted source of economic analysis requires high-quality work. Academic standards are the norm and they are maintained through various means. High-quality staff is a key factor and hiring is within the sole purview of the Director, ensuring a meritocratic personnel policy. CPB staff does research themselves, not only relying on available work done by others. This ensures maintenance of adequate analytical skills and sound judgment in the use of academic research done by others. Over time, CPB bolstered academic standards through a stronger focus on publications in academic journals and more interaction with academia. Research is now aimed at publication in a peer reviewed CPB series (CPB Discussion Papers), in international peer reviewed journals, as well as presentation at international seminars. CPB also expanded its network with Dutch economists through its circle of Academic Partners (professors accredited at universities). Some CPB staff members hold part-time positions at universities.

Policy relevance is safeguarded through frequent contacts with departments and other relevant policy makers. This feeds in both to the choice of topics to be analysed and proper institutional detail in the policy options discussed. Civil servants and other policy makers are consulted on the Work Program, while CPB can undertake research that is specifically funded by departments as well. Membership of the Social and Economic Council and several advisory committees within the government provides another channel of information and feedback. Research results are discussed in seminars with civil servants present. Publication of CPB Policy Briefs enhances the chance that research results will be used in policy-making. These short, non-technical papers on policy issues are specifically tailored to policy makers.

A final backstop to ensure non-partisan quality work is public external reviews. CPB's independent position does not mean that it is not accountable. CPB has a monitoring committee which commissions external reviews of both the policy relevance and the academic quality of the output on a regular basis. In the 2016 
edition, the Review Committee employed the protocol that is the standard in Dutch academia. It is also the first review that does not focus on just one aspect of CPB (policy relevance or academic standards), but that takes a look at the overall picture.

\subsection{CPB Products and Their Role in Policy Making}

Short and medium-term forecasting are the bread and butter of CPB. Four times a year CPB produces short-term forecasts for the Dutch economy, varying from growth, inflation and unemployment to the income distribution and public finances. These forecasts feed into the debate about the annual budget, with the CEP, published in March, serving as a starting point for the discussions on the expenditure side, and the MEV, published in September, as the finalization of the negotiations. In the run up to elections, CPB produces a medium-term forecast covering the full term in office of the new government. All these projections are made, using a standard macro econometric model (Saffier-II). ${ }^{1}$ Research into academically popular models like DSGE and BVAR did not yield a good alternative for this purpose, which requires a combination of projections, policy simulations and storytelling. CPB also produces the monthly World Trade Monitor, an empirical tool to follow actual developments in world trade and global industrial production. The World Trade Monitor is followed by forecasters across the world. At the specific request of Parliament, CPB also produces an annual Financial Risk Report. In the aftermath of the financial crisis, a clear need was felt to follow financial market developments more closely.

CPB regularly publishes long-term studies. Every 4 years, CPB analyses the sustainability of Dutch public finances (ageing studies). These projections are made using an Overlapping Generations Model (GAMMA). The issue of sustainable fiscal policy plays a major role in the Dutch political debate. Also other sustainability issues have become important in political manifestos and the election debates. Other long-term studies take the form of scenario analyses. On a regular basis, $\mathrm{CPB}$ presents a study with scenarios for welfare, prosperity and the quality of the living environment. ${ }^{2}$ This study provides the basic parameters for cost benefit analyses, which are mandatory for all large public investment projects. Other longterm scenario studies have been undertaken on a more ad hoc basis.

CPB aims to improve the efficiency and effectiveness of Dutch policy-making through evaluations. CPB undertakes ex ante cost benefit analyses of major investment projects (e.g. Business District Amsterdam, Afsluitdijk, Joint Strike Fighter) and provides the (binding) rules guiding such analyses. Examples of ex

\footnotetext{
${ }^{1}$ And a series of satellite models, such as a micro simulation model for purchasing power, labour costs, social security and income taxation (MIMOSI).

${ }^{2}$ In collaboration the Netherlands Environmental Assessment Agency (PBL).
} 
post evaluations of major policy reforms are the reorganization of social assistance and various education policies.

Institutional detail is essential to bridge the gap between academic research and the real world. CPB covers institutional issues in a number of areas, varying from the pension sector and financial institutions to health care. The results are widely used-from the Social and Economic Council to the government and parliament. Section 12.5 discusses some CPB studies in the field of labour market policies, illustrating how policy-related research may help improving growth prospects and competitiveness.

Finally, CPB plays a supporting role in the election process and the formation of a new government. CPB provides the medium-term economic scenario and the sustainability analyses before political parties start to draw up their manifestos. ${ }^{3}$ Since 1986, CPB offers any party with representation in the lower chamber of parliament the opportunity to have its program assessed. Parties are not required to partake, but almost all have done so, in line with expectations of the media and other political parties. Parties provide CPB with a financial translation of their manifesto (the measures are reported meticulously, so as to enable consistency checks with the manifesto itself by the media and other parties). This set of measures is then reviewed in various ways. First, an ex-ante budgetary test is applied, a kind of reality check: are the proposed measures feasible? Is the costing realistic? Second, a simulation is run, assuming that the party in question has the absolute majority in parliament, using the models mentioned before and more. This provides insights in the effects during the governing period of the next government on economic indicators (such as growth, inflation, unemployment, income distribution, budget) and on the long-term effects on labour supply and sustainable public finances. The results are published in a book entitled Charted Choices a couple of weeks before the election. This exercise sanitizes the debate, because it ensures a level of specificity in the proposals and prevents blatantly false statements.

The assessment of election manifestos has broadened over time. Originally, three parties took part, but in 2017 eleven party programs were assessed. The scope of analysis increased over time and the level of detail rose. The frequency of elections increased, making the available lead-time for the exercise more condense. To cope with this pressure cooker challenge, a series Promising Policies has been started, which is produced during non-election times. ${ }^{4}$ The series aims to provide an overview of policy options over a wide political spectrum in a number of policy areas, each with its pros and cons.

Once elections have taken place and a government is formed, CPB analyses the coalition agreement in a comparable manner.

${ }^{3}$ In the run up to Budget Day, political parties (generally opposition parties) have the opportunity to have their counter budget assessed by the CPB.

${ }^{4}$ The series is a co-production with the PBL and SCP (Netherlands Institute for Social Research). 


\subsection{Case Studies}

CPB contributes to the policy debate in different ways. This section illustrates CPB's role in four labour market reforms: the participation law aimed at creating employment for low-productive workers, fiscal labour market policy in general, the fiscal treatment of self-employment, and the state pension age. CPB is sometimes agenda setting, presenting an economic problem with sensible ways to address it. At other times its role is more passive, leaving the initiative to politicians and policymakers, in which case CPB typically gives an indication about the effects of different reforms. CPB may also act as a kind of referee. For instance, when different parties negotiate about a new policy and the goal is to reach a certain budget cut, CPB may assess whether the proposal will actually achieve this goal. Some practical examples will be given in the following subsections, with an overview table in the concluding subsection.

\subsubsection{Participation Law}

The 'Participation Law' is in effect since 1 January 2015. This law aims to improve the position of low-productive workers, and at the same time cut government expenses on social insurance. Before the enactment of the new law, expenses on the disability scheme for starters on the labour market (Wajong) were rising at a fast pace. A second reason for social insurance reform was that the Dutch public employment scheme (Wsw) was among the most expensive in the world. At the same time, the decentralization of social assistance to municipalities was considered a success. Thus, the main ingredients of the new law were to decentralize a large part of Wajong and Wsw to municipalities and simultaneously try to improve chances for low-productive workers to get a normally paid job. In particular, labour of lowskilled workers was made cheaper for employers by introducing wage subsidies.

Discussion about social insurance for low-productive workers started about a decade before the introduction of the Participation Law. In 2007, CPB drew attention to the rapidly rising number of 'Wajong'-benefit recipients. ${ }^{5}$ The number of recipients then equalled about 150,000 (Fig. 12.1). By 2014, it had risen to 250,000 , which is $2.5 \%$ of the total population between the ages of 20 and 65 . In 2010, a commission reported on different options for reforming both the Wajong and the public employment scheme Wsw. ${ }^{6}$ The Wsw ('Social workplaces') was not

\footnotetext{
${ }^{5}$ See Suijker (2007). By the end of 2006 the cabinet had already asked the Social and Economic Council (SER) for an advice on the Wajong. But CPB's publication on the matter gave the problem broader attention.

${ }^{6}$ See Werkgroep brede heroverwegingen (2010). The goal of this commission was to find ways to cut budget expenditures after the start of the economic crisis in 2008. Apart from Wajong and Wsw, many other policy options were studied in different reports.
} 


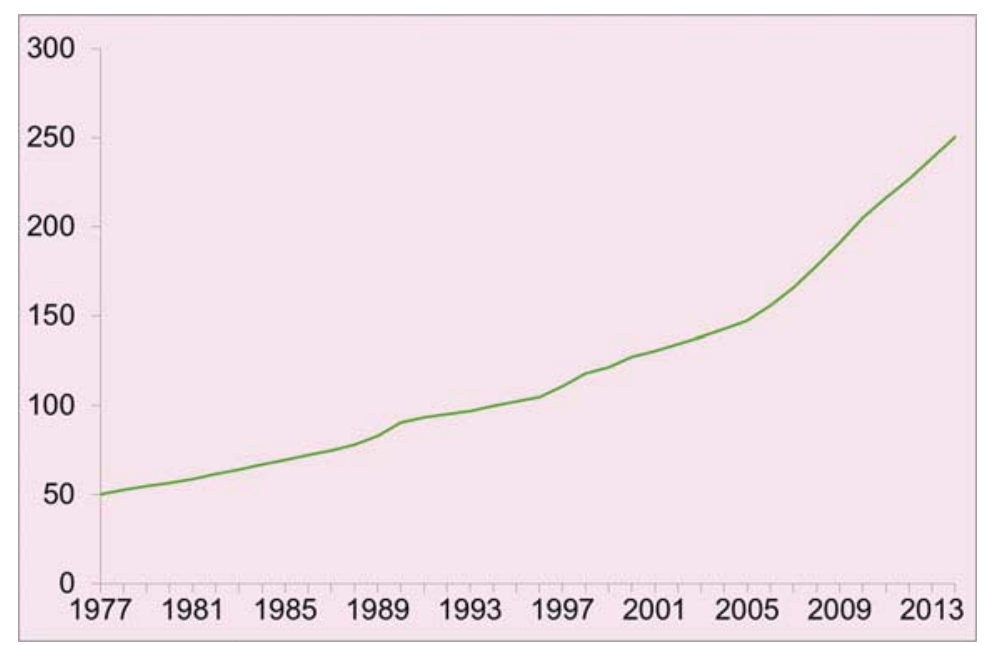

Fig. 12.1 Number of Wajong-benefit recipients $(\times 1000)$. Source: UWV

considered successful, being one of the most expensive public employment schemes in the western world, while virtually none of the participants could use their public job as a stepping stone towards a normally-paid job.

In 2004, the then-state secretary of Social Affairs Mark Rutte decentralized social assistance to municipalities. Municipalities became responsible for the administration of social assistance and the re-integration into a normally paid job of its recipients. The decentralization involved an important financial incentive for municipalities to contain their social assistance rolls. Municipalities receive a fixed budget to cover the social assistance costs. If they spend less municipalities may keep the money but if they spend more they will have to cover the additional costs from other sources. An early estimation by $\mathrm{CPB}$ concludes that the expenditures on social assistance have been lowered by about $6 \%$ as a result of this decentralization (Van Es 2010; Van Es and van Vuuren 2010).

In 2011, CPB published a discussion paper on the Wajong in combination with social assistance (SA), which was followed by a Policy Brief (Roelofs and van Vuuren 2011; Van Vuuren et al. 2011). In these publications, CPB argued that the use of Wajong was for an important part a result of the decentralized SA budgets. Municipalities had an incentive to redirect SA-recipients towards the centrally financed Wajong-scheme, which at that time was a close substitute for many SA recipients. According to $\mathrm{CPB}$ estimates, nearly half of the Wajong enrolment in 2006 and 2007 was related to the decentralization of SA. The policy advice was therefore to put (the substitutable part of) Wajong and SA in the same hand, namely that of municipalities. This advice boosted the debate on Wajong and Wsw and helped the government to reform the system. 


\subsubsection{Fiscal Labour Market Policy}

In CPB's assessment of fiscal labour market policies, the focus is usually on structural employment effects, budgetary effects, and the effects on purchasing power. ${ }^{7}$ Overview publications with univariate policy changes are produced on a regular basis. In this way, policy makers are continuously made aware of the effects of 'standard' fiscal measures, such as lowering the tax rate in a specific tax bracket or increasing the Earned Income Tax Credit (see CPB 2015b). In addition to these regular publications, specific analyses are done at the request of political parties and departments. For instance, plans for a flat tax or a basic income reform have been assessed by CPB (see Jongen et al. 2015).

The effects of fiscal labour market policies are usually assessed using the microsimulation model 'MICSIM' (see Jongen et al. 2014). This model is evidence-based, i.e. largely based on empirical analyses of Dutch data. For instance, labour supply elasticities for men and women were estimated (see also Chap. 11) and are now part of the MICSIM model. A recent finding is that labour supply elasticities of women are still substantially higher than for men-especially on the extensive margin, i.e. the decision to either participate in the labour market or not (Fig. 12.2). But the difference between men and women is substantially smaller than in earlier years (see Evers et al. 2008). The MICSIM model provides an integrated model, i.e. the impact of policy changes on main indicators (structural employment, income inequality, and productivity) result from the same framework.

Table 12.2 shows some policy simulations with MICSIM. ${ }^{8}$ In terms of structural employment, it turns out that lower health care allowances or child allowances generate positive effects. These reductions lead to a lower implicit marginal tax rate for lower-income households, encouraging these relatively elastic households to increase their labour supply. The downside is, however, that poverty among low-income households increases. A higher Earned Income Tax Credit (EITC) for the lowest incomes is also beneficial for structural employment, but in this case the 'price' is paid by the government budget and not so much by lower income households. Lowering income tax rates is-given the budgetary impulse-less successful in terms of its impact on structural employment.

\subsubsection{The Fiscal Treatment of Self-Employment}

Self-employment in the Netherlands has been growing at a fast pace. Since 2003, the number of self-employed workers has grown by more than $50 \%$, towards about 1 million individuals, whereas the number of employed workers remained more or

\footnotetext{
${ }^{7}$ Also, effects on productivity are sometimes reported, see e.g. CPB (2015b).

${ }^{8}$ These examples are drawn from CPB (2015b).
} 


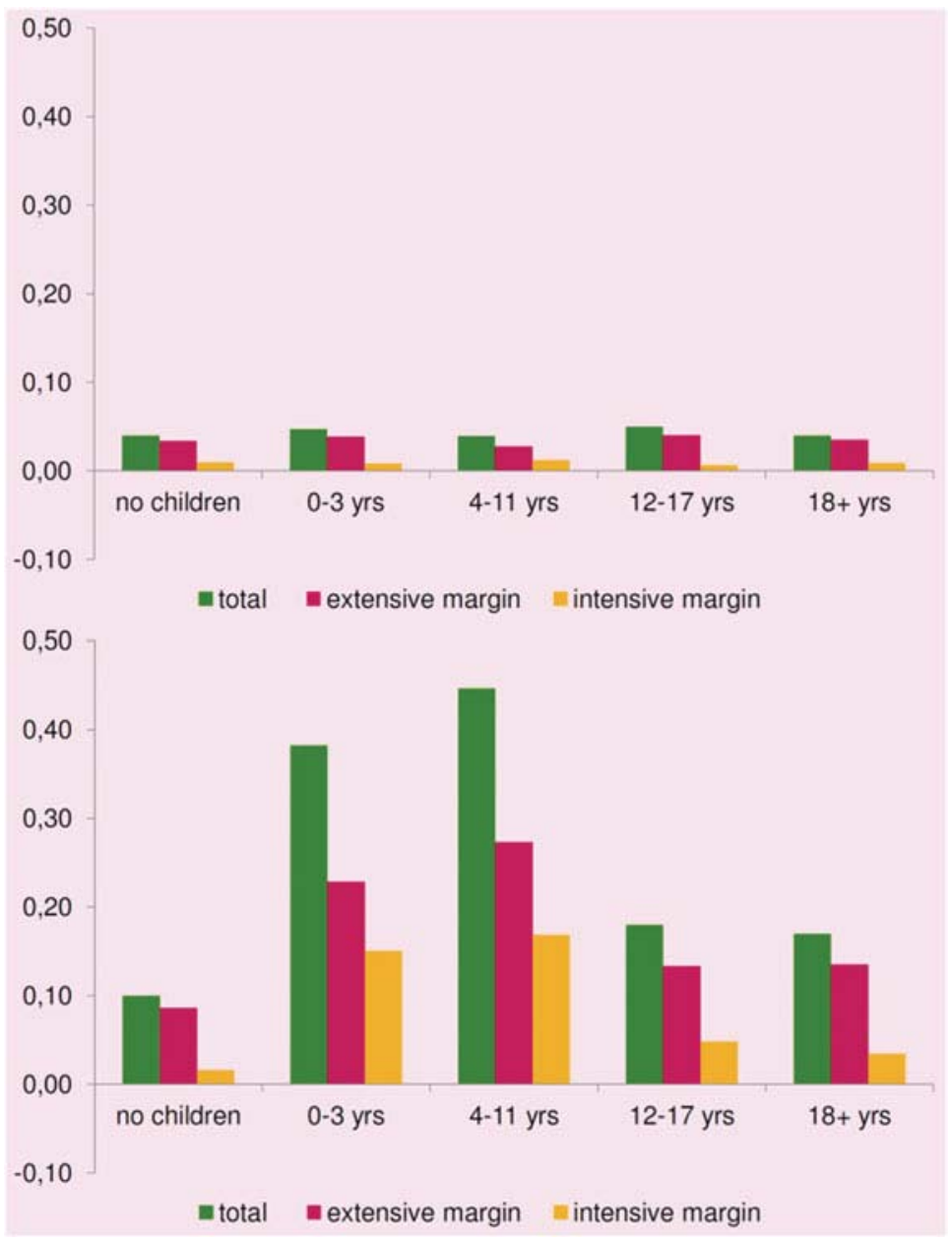

Fig. 12.2 Labour supply elasticities of men (left) and women (right) in couples

less constant (Fig. 12.3). This development has raised concerns about institutional factors encouraging self-employment and discouraging wage employment. The hypothesis that institutional factors have driven the growth in self-employment seems to be confirmed by a decomposition analysis, which finds that less than half of this growth can be explained by socio-demographic and macro-economic determinants (Van Es and van Vuuren 2011). Therefore, more than half of the growth is likely related to institutions and/or social norms.

The precise effect of fiscal incentives on the growth of self-employment has not been quantified yet, but a look at the difference in tax rates between self-employed and employees shows that this might be an obvious explanation (Fig. 12.4). The marginal tax rate is typically $15-25 \%$ points lower for self-employed than for 
Table 12.2 MICSIM-simulations: some examples

\begin{tabular}{l|l|l|l|l|l}
\hline & $\begin{array}{l}\text { Budgetary effect } \\
\text { (billion euros) }\end{array}$ & $\begin{array}{l}\text { Employment } \\
(\% \text { change })\end{array}$ & $\begin{array}{l}\text { Productivity } \\
(\% \text { change })\end{array}$ & $\begin{array}{l}\text { Gini-coefficient } \\
(\% \text { change })\end{array}$ & Remarks \\
\hline $\begin{array}{l}\text { Lower health } \\
\text { care allowance } \\
\text { (zorgtoeslag) }\end{array}$ & +1.5 & +0.4 & -0.1 & +1.4 & $\begin{array}{l}\text { Negative } \\
\text { disposable } \\
\text { income effects } \\
\text { for low-income } \\
\text { households }\end{array}$ \\
\hline $\begin{array}{l}\text { Lower child } \\
\text { allowance } \\
\text { (kindgebonden } \\
\text { budget) }\end{array}$ & +0.5 & +0.3 & 0.0 & +0.5 & $\begin{array}{l}\text { Negative } \\
\text { disposable } \\
\text { income effects } \\
\text { for low-income } \\
\text { households } \\
\text { with young } \\
\text { children }\end{array}$ \\
\hline $\begin{array}{l}\text { EITC for } \\
\text { lowest incomes }\end{array}$ & -1.5 & +0.2 & -0.1 & -0.3 & $\begin{array}{l}\text { Positive } \\
\text { disposable } \\
\text { income effects } \\
\text { for low-income } \\
\text { households }\end{array}$ \\
\hline $\begin{array}{l}\text { Lower income } \\
\text { taxes }\end{array}$ & -1.5 & {$[0.0,+0.1]^{\mathrm{a}}$} & 0.0 & {$[-1.0,-0.3]^{\mathrm{a}}$} & $\begin{array}{l}\text { Positive } \\
\text { disposable } \\
\text { income } \\
\text { effects }\end{array}$ \\
\hline
\end{tabular}

${ }^{a}$ The exact size of the effect depends on the tax bracket. Disposable income effects are positive for low-income households if the tax rate in the lowest tax bracket is lowered, etc.

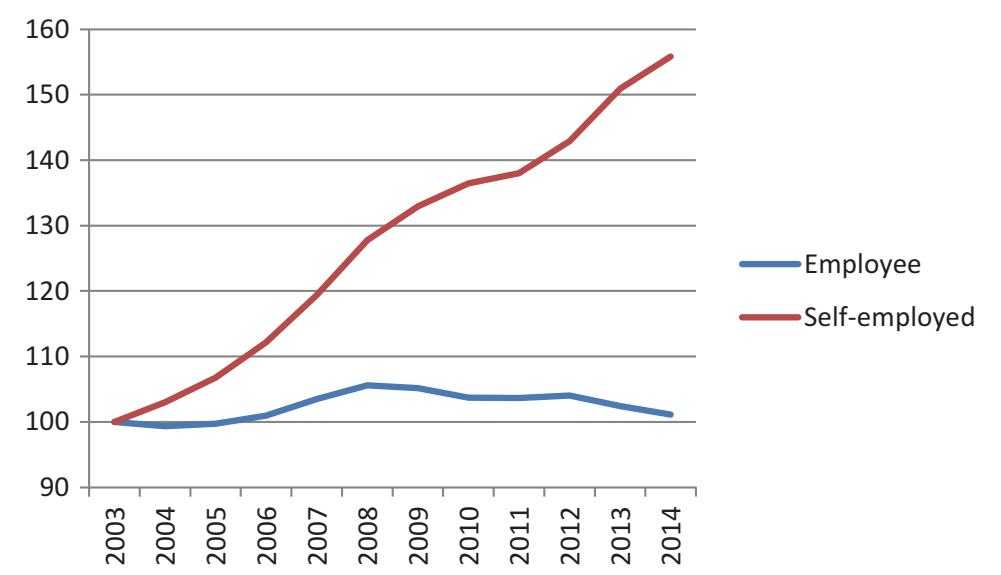

Fig. 12.3 Self-employment grows; wage employment does not $(2003=100)$

employees, and the average tax rate is typically about $20 \%$ points lower. The tax incentive is likely one of the explanatory factors for the growth of self-employment.

In 2012, CPB published a critical assessment about the fiscal stimulation of self-employment (Van Vuuren 2012). Some possible arguments in favour of fiscal 

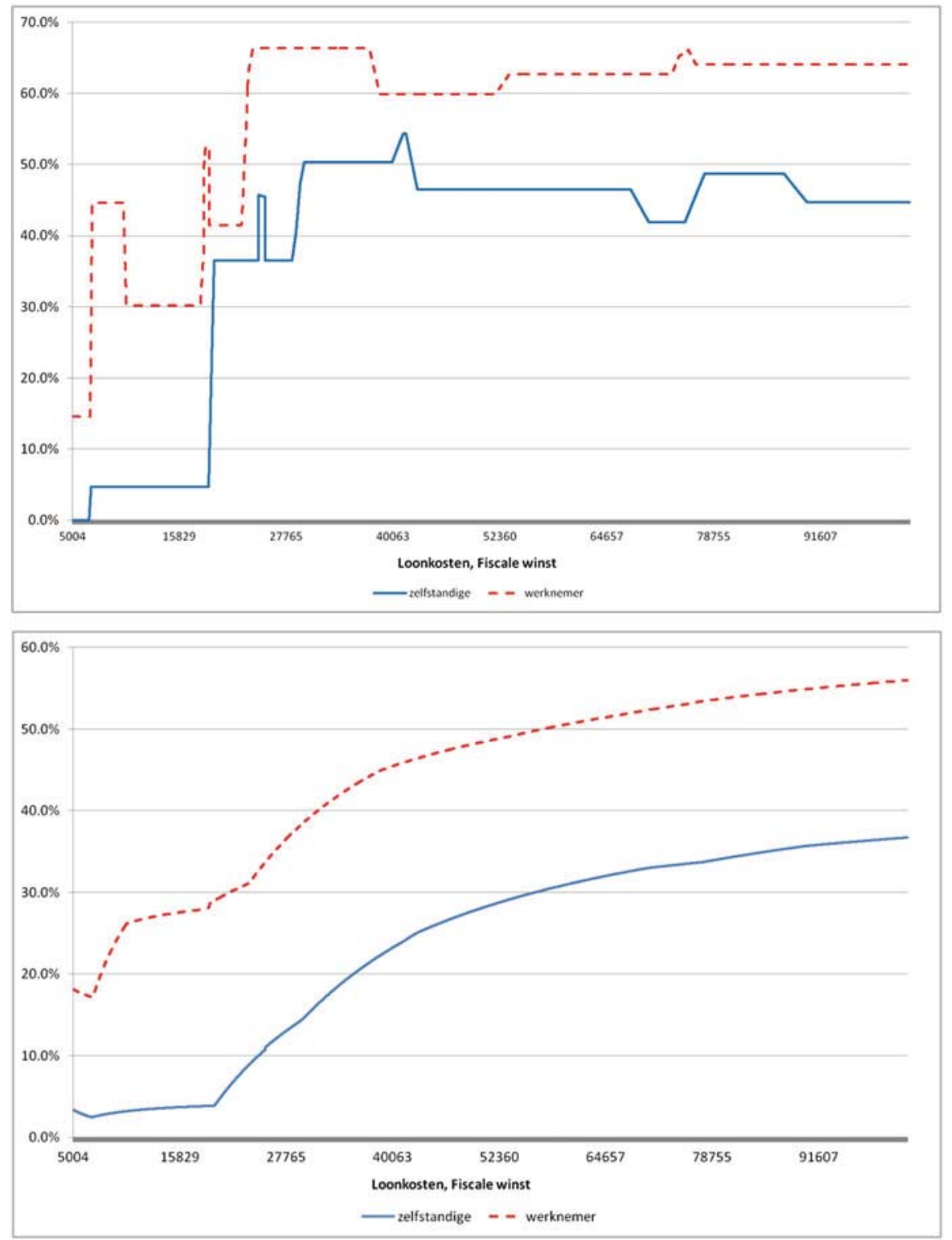

Fig. 12.4 Effective marginal tax rate (left) and average tax rate (right) for employees (dashed line) are higher than for self-employed

stimulation were considered, such as employment growth and the stimulation of innovation, but mostly rejected. Consequently, the government coalition agreement 'Bruggen Slaan' in 2012 included measures to lower the fiscal stimulation of selfemployment, in particular the so-called 'Zelfstandigenaftrek'. However, due to a 
lack of political support, no policy measures in line with CPB's assessment have been taken so far.

In 2014, the cabinet installed a commission to study the phenomenon of selfemployment and develop policy options on how it could be dealt with. The report was published in 2015, with policy options in line with CPB's earlier assessments. ${ }^{9}$ The government has, however, decided not to take action yet, and leave further policies to the next government (Asscher and Kamp 2015).

\subsubsection{Raising State Pension Age}

In 1997 and 2000, CPB drew attention to the effect of ageing on the sustainability of government finances (CPB 1997; Van Ewijk et al. 2000). As a result of the ageing population, government expenditures would rise more than tax revenues. This would result in a gap in the government budget. Expenditure reduction and/or increasing tax revenues would be necessary in order to avoid this gap. A way to achieve this was to stimulate labour force participation, in particular by reducing social security expenditures. Raising the state pension age would obviously fit into this policy, as it would both reduce state pension expenditures and increase tax revenues as a result of higher labour force participation.

In 2009, the government planned to increase the entitlement age for the state pension 'AOW'. Government expenditures on AOW were close to 5\% of GDP at that time, and according to $\mathrm{CPB}$ projections would rise to 6\% in 2020 and $8 \%$ in 2040. However, the trade unions did not accept the government plans and the government gave them room to formulate an alternative policy within 6 months in the context of the Social and Economic Council (SER). Apart from the unions, the SER consists of representatives of employer organizations and experts (including CPB) appointed by the government. The government imposed a restriction on the alternative policy, namely that it should structurally improve the government budget by $0.7 \%$ GDP. This figure was computed by CPB as the budgetary effect that would result from increasing retirement age from 65 to 67 (CPB 2009a).

During these 6 months, many alternative policies were studied and CPB had to assess the long-term budgetary impact of each one of them. For instance, increasing the retirement age in combination with a flexible pension age was studied, as were separate arrangements for workers in 'physically demanding jobs' and older unemployed workers. However, the SER negotiations failed, and by the end of 2009 the government announced that the retirement age would be stepwise raised by 2 years. CPB again provided quantitative input for these proposals (CPB 2009b, 2010).

${ }^{9}$ See IBO Zelfstandigen zonder personeel (2015). CPB (2015a) brought out a report for the commission at its request. 


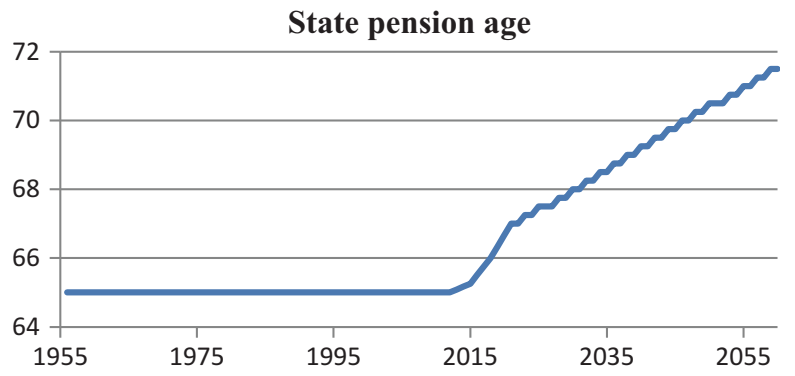

Fig. 12.5 The path for increasing the state pension age, starting in 2015. Notes: the increases after 2021 are based on current estimations of future life expectancy developments. The steps may turn out different in the future in case actual life expectancy developments deviate from these expectations

The new government accelerated these steps in 2012, and on top the retirement age was structurally tied to the 'residual life expectancy'. This has resulted in a stepwise path for the AOW age as shown in Fig. 12.5. The automatic link between the retirement age and residual life expectancy has importantly improved the sustainability gap and made long-term government finances more robust (Smid et al. 2014).

\subsubsection{Conclusion}

CPB has played five different roles in the four cases discussed in this chapter. Table 12.3 summarizes these roles.

CPB has played - and continues to play in some cases - an agenda-setting role. Examples are the Wajong, the fiscal treatment of self-employment, and the legal retirement age. The issues were known before CPB published about it, but became more important in the policy debate when CPB provided in-depth analyses and figures. Attention for the state pension age was generated indirectly, by publishing reports about the long-term sustainability of government finances. These reports made clear that increasing the state pension age would be one of the most obvious measures to counter the long-term budgetary deficit due to aging. With Wajong and the state pension age, actions in the form of new legislation have been taken already. The fiscal treatment of self-employment has seen little action yet, but will likely be addressed by the next government. With the analysis of fiscal labour market policies, CPB's role is more demand-driven. Outcomes of standard fiscal policies have been published every once in a while.

CPB plays a more structural role in the analysis of fiscal labour market policies. Some fiscal measures are 'standard', like adjusting tariffs in the income tax, and their effects have regularly been published. In this case, CPB's agenda-setting role is smaller, although there can be an indirect effect. For instance, intensifying child- 
Table 12.3 CPB's different roles in the four cases discussed

\begin{tabular}{l|l|l|l|l}
\hline & $\begin{array}{l}\text { 1. Participation } \\
\text { law }\end{array}$ & $\begin{array}{l}\text { 2. Fiscal } \\
\text { labour market } \\
\text { policies }\end{array}$ & $\begin{array}{l}\text { 3. Fiscal treatment of } \\
\text { self-employment }\end{array}$ & $\begin{array}{l}\text { 4. State pension } \\
\text { age }\end{array}$ \\
\hline Agenda setting & Yes & Sometimes & Yes & Indirectly \\
\hline $\begin{array}{l}\text { Permanent } \\
\text { source of } \\
\text { information }\end{array}$ & & Yes & & \\
\hline $\begin{array}{l}\text { Act as referee } \\
\text { during } \\
\text { negotiations }\end{array}$ & & & & Yes \\
\hline $\begin{array}{l}\text { Assist } \\
\text { departments in } \\
\text { quantifying } \\
\text { effects }\end{array}$ & Yes & Yes & Not yet & Yes \\
\hline $\begin{array}{l}\text { Assist } \\
\text { politicians in } \\
\text { quantifying } \\
\text { effects }\end{array}$ & Yes & Yes & & \\
\hline
\end{tabular}

care subsidies became less popular after CPB's assessment that they would have a much smaller effect on the labour participation of women than previously thought (Jongen 2010).

CPB has acted as a referee when the pension age reform was discussed among social partners. The government had imposed the restriction that the reform should improve the government budget in the long term by $0.7 \%$ of GDP. During the negotiation process between the social partners, CPB assessed whether this goal would be achieved. (And in most proposals, it wasn't.)

Finally, CPB has assisted both ministries and political parties with quantifying the effects of proposals. Before the approval of the Participation Law, several other proposals have been assessed by CPB. In the context of reforming the tax system, $\mathrm{CPB}$ has calculated the effects of different variants. It is quite common that $\mathrm{CPB}$ either quantifies the effects of policy proposals or checks the quantifications made by the ministries themselves. Requests from politicians, e.g. members of parliament, take place regularly. For instance, in the case of the participation law, CPB was asked to inform the Dutch parliament about the effects (CPB 2012).

\subsection{EU Policy Initiatives and the Dutch Experience: Some Pointers}

Some initiatives in the aftermath of the Eurozone crisis seem to echo the Dutch experience with CPB. Arguments favouring independent policy-making have been widely accepted in the monetary policy arena, but its application in other areas has traditionally been less straightforward. Choices in labour and product market 
regulation reflect political preferences, and 'no taxation without representation' is considered a starting point of democracy. The move towards Independent Fiscal Institutes, the decision to establish a European Fiscal Board and the recent Recommendation to establish National Productivity Boards can be seen as experiments in this direction.

The Fiscal Compact and Two Pack require countries to have an Independent Fiscal Institute that (1) endorses or produces the macro-economic and budgetary forecasts in the national budget, and (2) assesses whether the correction mechanism for significant deviations need to be activated or alternatively factors have occurred which may allow for temporary deviations. As such, the Two Pack mixes positive and normative elements; monitoring of indicators needs to be supplemented with judgement of any discrepancies. In the Five Presidents' report the creation of a European Fiscal Board (EBF) was suggested and recently the European Commission decided to establish one (albeit with a somewhat different mandate). According to the Commission's decision, the EBF will (1) evaluate the implementation of the EU fiscal framework (with room for suggestions for the future evolution of the Union fiscal framework), (2) advise on the fiscal stance for the euro area as a whole and (3) cooperate with national fiscal councils. Recently, the Council adopted a recommendation to establish National Productivity Boards (NPBs) with as tasks (1) diagnosis and monitoring of productivity and competitiveness developments and its drivers, (2) independent analysis of policy challenges in this area and, where relevant, assessment of policy options. The NPB should engage with other NPBs with the aim of exchange views etc., as well as the Commission.

With the Dutch experience in mind, the following lessons come to the fore. First: water and oil don't not mix. A division of labour between those producing the facts and analyses and those who decide on policy is a good thing. It enhances a levelheaded debate on policy goals and options. This is not to say that producing forecast and analyses is straightforward and value-free per se, but the temptation to doctor the figures is taken out of the equation.

Second: never waste a good crisis. CPB was established in 1945, just after WWII and a deep financial crisis in the 1930s. When things are difficult, the desire for evidence-based policy to solve issues effectively and efficiently may be strongest. The introduction of IFIs during the Great Recession and the recommendation for NPBs reflect this as well.

Third: with a little help from my friends. IFIs or NPBs do not need to start out on their own, from scratch. Existing institutes can become responsible for these tasks. There is nothing wrong with borrowing credibility from existing institutes, like a National Audit Office or a central bank.

Fourth: Rome was not built in a day. In 2015, CPB turned 70. It took time to establish a reputation as a dependable source of economic forecasts and analyses. The portfolio has been expanded gradually. The institute has started modestly and built on its successes.

Fifth: facts speak louder than opinions. The fiscal framework unfortunately requires IFIs to come up with judgments. The mix of positive and normative analysis increases the risk of political appointees. It also makes it easier for politicians to 
ignore the facts, arguing that they are just personal opinions. An option here is to divide the tasks over two institutes, like the Netherlands has done, or alternatively present the facts and the opinions in separate documents. The IFI regulation cannot be easily adapted. Fortunately, the normative bit was eliminated in the final NPB recommendation.

Sixth: bottom up is best. The strive towards evidence-based policy will work best if institutions are perceived as locally owned, geared towards local issues and problems, and able to provide bespoke solutions. This argues against tasks that might be perceived as policing on behalf of the European Union, such as presently incorporated in the IFI, but fortunately skipped in the NPBs mandate.

Seventh: panta rhei. Competitiveness is a multi-faceted and ever changing concept. This argues against fixating on a simple score board and favours a broad mandate so that the study of the economy and relevant policies can change over time. The case studies in this paper have underscored this point.

Finally: practice what you preach. At the EU level, economic forecasts that feed into SGP procedures are not the product of an independent or autonomous body. Moreover, the EU does not possess an independent body to analyse and evaluate Commission policy or to commission economic research. The Commission's decision on the European Fiscal Board seems a missed opportunity.

\section{References}

Asscher L, Kamp H (2015) Aanbieding kabinetsreactie IBO ZZP, letter to the Dutch parliament on behalf of the cabinet, ministries of Social Affairs and Economic Affairs

Bos F, Teulings C (2012) The Dutch CPB: what can be learned from the world's oldest fiscal watchdog? VOX EU

Council (2016) Council Recommendation of 20.9.2016 on the establishment of National Productivity Boards (2016/C 349/01)

CPB (1997) Centraal Economisch Plan 1997

CPB (2009a) Houdbaarheidseffect verhoging AOW-leeftijd. CPB Notitie

CPB (2009b) Houdbaarheidseffect voorstel verhoging AOW-leeftijd. CPB Notitie

CPB (2010) Analyse voorstel verhoging AOW-leeftijd. CPB Notitie

CPB (2012) Notitie voor rondetafelgesprek Tweede Kamer over de Wet Werken naar Vermogen (WWNV). CPB Notitie

CPB (2015a) Position paper t.b.v. 'IBO zelfstandigen zonder personeel'. CPB Notitie

CPB (2015b) Kansrijk Arbeidsmarktbeleid. Serie Kansrijk Beleid CPB/PBL/SCP

Evers M, de Mooij R, van Vuuren D (2008) The wage elasticity of labour supply: a synthesis of empirical estimates. De Economist 156:25-43

Five Presidents' Report (2015) Plans to strengthen Economic and Monetary Union as of 1 July 2015

IBO Zelfstandigen zonder personeel (2015) Eindrapport IBO Zelfstandigen zonder personeel

Ipsos (2015) Bekendheid- en reputatieonderzoek Centraal Planbureau (CPB)

Jongen E (2010) Child care subsidies revisited. CPB Document 200

Jongen E, de Boer H, Dekker P (2014) MICSIM: a behavioural microsimulation model for the analysis of tax-benefit reform in the Netherlands. CPB Background Document

Jongen E, de Boer H, Dekker P (2015) De effectiviteit van fiscaal participatiebeleid. CPB Policy Brief, 2015/02 
Passenier J (1994) Van planning naar scanning, Een halve eeuw Planbureau in Nederland, WoltersNoordhoff

Roelofs G, van Vuuren D (2011) The decentralization of social assistance and the rise of disability insurance enrolment. CPB Discussion Paper 185

Smid B, ter Rele H, Boeters S, Draper N, Nibbelink A, Wouterse B (2014) Minder zorg om vergrijzing. CPB Book 12

Suijker F (2007) Verdubbeling van de instroom in de Wajong: oorzaken en beleidsopties. CPB Document 156

van Es F (2010) Invloed WWB op gebruik bijstand. CPB Document 209

van Es F, van Vuuren D (2010) Minder uitkeringen door decentralisering bijstand. Economisch Statistische Berichten 91:408-410

van Es F, van Vuuren D (2011) A decomposition of the growth in self-employment. Appl Econ Lett 18:1665-1669

van Ewijk C, Kuipers B, ter Rele H (2000). Ageing in the Netherlands. CPB Special Publication 25

van Vuuren D (2012) De fiscale behandeling van zelfstandigen: een kritische blik. CPB Policy Brief 2012/2

van Vuuren D, van Es F, Roelofs G (2011) Van bijstand naar Wajong. CPB Policy Brief 2011/9

Werkgroep brede heroverwegingen (2010) Op afstand van de arbeidsmarkt. Rapport 9 uit de brede heroverwegingen 